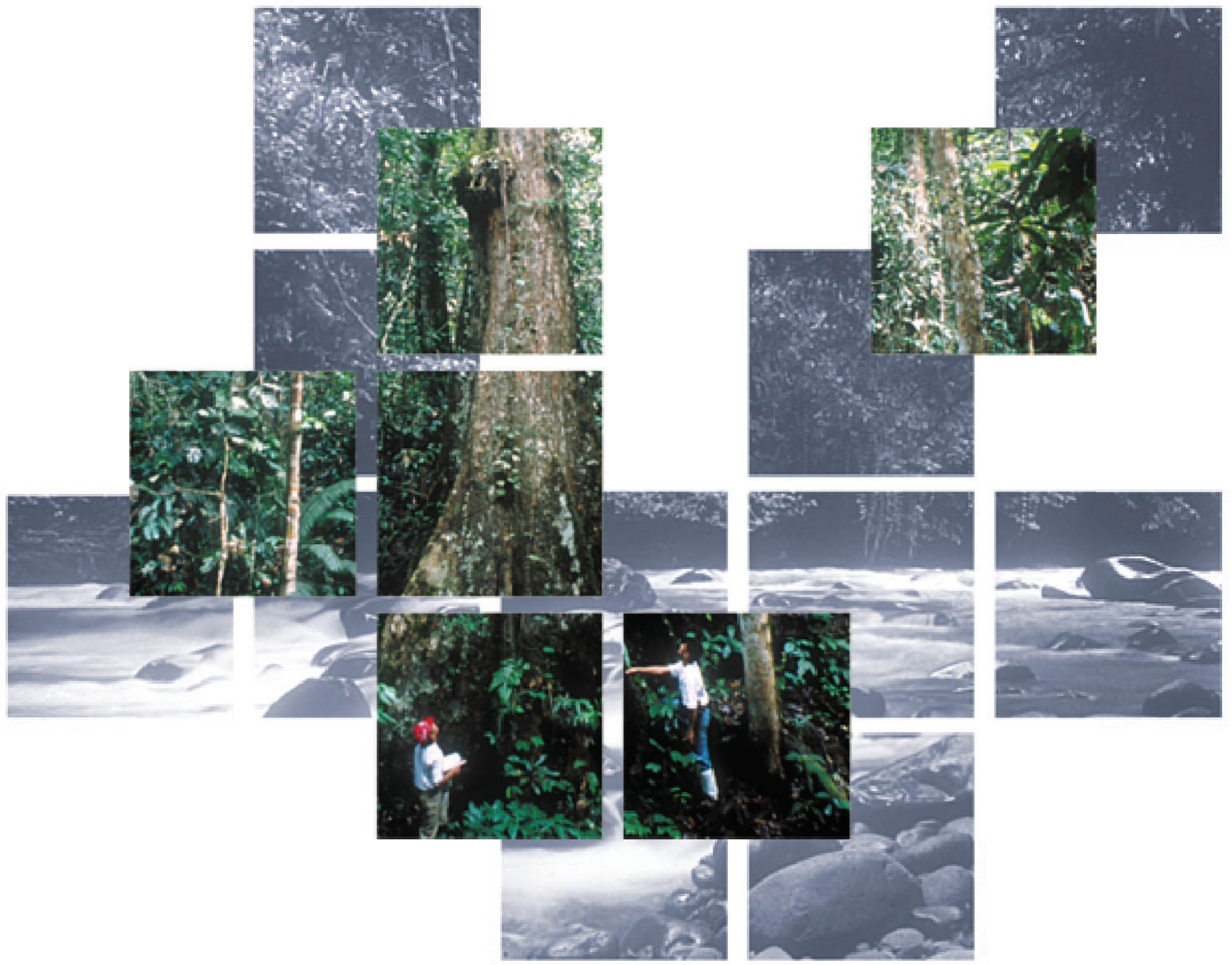

\title{
Pedoman Umum
}

Penyusunan

Peraturan Daerah

Pengelolaan Hutan

Jason M. Patlis

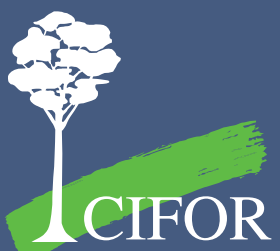




\section{Pedoman Umum Penyusunan Peraturan Daerah Pengelolaan Hutan}

Jason M. Patlis 
Penulis, Jason M. Patlis, adalah pakar di bidang hukum sumberdaya alam dan pemerintahan. Beliau melakukan studi mengenai isu-isu sumberdaya alam di Indonesia sejak tahun 2000, ketika menerima Beasiswa Fulbright. Sebelumnya, beliau bertugas pada Pemerintah Amerika Serikat selama hampir 10 tahun, antara lain selama tahun 1997 - 2000 sebagai Majority Counsel untuk Komite Lingkungan dan Sumberdaya Alam di dalam Senat Amerika Serikat.

Beliau sekarang bekerja sebagai Penasihat Hukum Senior untuk Proyek Pengelolaan Sumberdaya Alam Pesisir yang dibiayai USAID, dimana beliau memimpin program reformasi hukum dengan bekerja dengan institusi dan pihak terkait di tingkat regional dan nasional, untuk memperbaiki kerangka hukum dan kelembagaan dalam pengelolaan pesisir dan sumberdaya alam.

Foto cover oleh Herwasono Soedjito

(c) 2004 by Center for International Forestry Research

Hak cipta dilindungi. Diterbitkan tahun 2004

Dicetak oleh Rediprint

ISBN 979-3361-43-3

Diterbitkan oleh

Center for International Forestry Research

Alamat pos: P.O. Box 6596 JKPWB, Jakarta 10065, Indonesia

Alamat kantor: Jl. CIFOR, Situ Gede, Sindang Barang,

Bogor Barat 16680, Indonesia

Tel. : +62 (251) 622622

Fax. : +62 (251) 622100

E-mail: cifor@cgiar.org

Situs: http: / /www.cifor.cgiar.org 


\section{Daftar Isi}

Ucapan Terima Kasih $\quad$ iv

Abstrak

I. Pendahuluan 1

II. Kerangka Kerja Hukum dan Perundang-undangan Saat Ini 3

III. Tanggung Jawab Pemerintah Daerah Kabupaten/Kotamadya $\quad 7$

IV. Prinsip-prinsip Penyusunan Peraturan Daerah tentang Kehutanan 10

V. Mekanisme Penyusunan Peraturan Daerah tentang Kehutanan 21

$\begin{array}{ll}\text { VI. Kesimpulan } & 25\end{array}$

$\begin{array}{ll}\text { Daftar Pustaka } & 27\end{array}$ 


\section{Ucapan Terima Kasih}

Penulis mengucapkan terima kasih kepada CIFOR, yang mendukung penelitian dan penerbitan pedoman ini. Ucapan terima kasih khususnya ditujukan kepada tim CIFOR di Long Loreh, Malinau, Kalimantan Timur, termasuk Godwin Limberg, Njau Anau, Ramses Iwan, dan khususnya I Made Sudana, atas saran, bimbingan, petunjuk, pengetahuan, dorongan, dan kebersamaannya. Terima kasih juga untuk staf CIFOR di Bogor, termasuk Carol Colfer yang pertama kali memutuskan untuk melakukan penelitian ini; Lini Wollenberg yang telah memberikan pengarahan terusmenerus; dan juga kepada Chris Barr, Moira M. Moeliono dan Tony Djogo. Secara khusus penulis mengucapkan terima kasih kepada Dina Juliarti Hubudin, yang tanpa kenal lelah telah banyak membantu dalam menyelesaikan masalah-masalah logistik.

Penulis juga ingin mengucapkan terima kasih kepada masyarakat Malinau yang dengan sabar telah menjawab pertanyaan-pertanyaan selama wawancara dan diskusi informal. Terima kasih juga penulis sampaikan kepada para pemuka masyarakat dan perorangan termasuk Ipo Kre, Lungu Impang, Markus Impang, Yusuf Incau, Alan Lawing, Aran Alang Phi, Alang Lungu, Ipo Boy, Iran Usat, Martin dari Senteban,
Armin Argung, Alan Laing, Ingan Ipo, Unyat Iman, Abia di Long Bila. Juga kepada para pejabat pemerintah daerah termasuk Pak Khariul, Pak Saparuddin, Pak Moses Gurodaboro, dan Pak Iwan Ajang, penulis sampaikan terima kasih.

Penulis juga berterima kasih kepada mereka yang telah membantu menyampaikan berbagai gagasan, saran dan inspirasinya: Wiwiek Awiati, Chip Barber, Chris Bennett, Paul Breitzke, David Brown, Tim Brown, Mario Buccocci, Wahyuningsih Darajati, Ian Dutton, Elfian Effendi, Chip Fay, Sapta Putra Ginting, Koesnadi Hardjasoemantri, Jeff Hayward, Laurel Heydir, Marc Hiller, Azis Khan, Nalin Kishor, Maurice Knight, Owen Lynch, Reed Merrill, Mering Ngo, Nonette Royo, Mas Achmad Santosa, Ann dan Bob Seidman, Sulaiman Sembiring, Michael Sinclair, Daud Silalahi, Scott Stanley, Kathleen Surcliffe, Ronald Titahelu, Sukma Violetta, dan Adi Wiyana.

Penelitian ini didanai bersama oleh Fulbright Senior Scholarship, 2000-2001 dan CIFOR. Sedangkan biaya penterjemahan dan distribusi tulisan ini disediakan oleh the Program on Forests (PROFOR).

Semua pendapat yang tertuang dalam tulisan ini merupakan pandangan pribadi penulis dan bukan merupakan pandangan CIFOR.

Jason M. Patlis

Juni 2004

jason@yourearth.net 


\section{Abstrak}

Sejak diberlakukannya kebijakan otonomi daerah, tata pemerintahan Indonesia telah mengalami perubahan yang amat cepat. Kewenangan pengelolaan daerah sekarang berada di tangan sekitar 420 Pemerintah Daerah (Pemda) Kabupaten dan Kotamadya. Dalam menjalankan kewenangan baru ini, Pemda Kabupaten/Kotamadya bertanggung jawab untuk memastikan bahwa Peraturan Daerah (Perda) dan kebijakan yang dibuatnya konsisten dengan Undang-Undang dan kebijakan Pemerintah Pusat. Mereka juga bertanggung jawab untuk menyusun Perda yang mengutamakan kepentingan masyarakat dan menerapkan prinsip-prinsip tata kelola pemerintahan yang baik dan bertanggung jawab (good governance) untuk menjamin bahwa sumber daya alam yang dimilikinya dimanfaatkan secara lestari. Meskipun Perda yang disusun secara umum sering mengacu kepada tiga pilar tata kelola pemerintahan yang baik (akses kepada informasi, partisipasi, dan keadilan), belum ada pedoman untuk bagaimana menerapkannya di lapangan. Selain itu, pada umumnya tidak ada metoda yang digunakan secara konsisten dalam menyusun Perda yang baru.

Tulisan ini menyajikan pedoman umum untuk mengembangkan Perda pengelolaan sumber daya hutan. Dalam pedoman ini pertama kali dipaparkan tanggung jawab Pemda; kemudian dijelaskan beberapa prinsip penting yang sebaiknya diterapkan dalam menyusun Perda, serta beberapa alternatif kemungkinan penerapannya. Setelah itu diuraikan metodologi untuk menyusun Perda baru. Pedoman ini menyarankan alternatif dan cara-cara yang dapat dilakukan oleh kabupaten/kotamadya yang memiliki keterbatasan dana dan pengalaman untuk melakukan penyempurnaan dalam penyusunan Perda baru tentang pengelolaan kehutanan. 


\section{Pendahuluan}

Sejak jatuhnya Presiden Suharto pada tahun 1998 dan dimulainya era reformasi, terdapat dua perubahan tata hukum dan perundang-undangan yang sangat mencolok. Yang pertama adalah bahwa perumusan peraturan beralih dari Pemerintah Pusat kepada Pemerintah Daerah (Pemda); dan yang kedua, pergeseran proses dari lembaga eksekutif kepada lembaga legislatif. Kedua perubahan ini berpotensi besar untuk memperbaiki kerangka kerja hukum dan perundangan pengelolaan sumber daya hutan. Banyak studi yang telah membahas berbagai manfaat desentralisasi dalam hal efisiensi, transparansi, tanggung gugat, dan daya tanggap (Asia Foundation, 2002). Banyak pustaka yang menyebutkan penurunan tingkat korupsi yang terkait dengan pengelolaan yang terdesentralisasi (Fisman dan Gatti, 1999). Manfaat serupa diperoleh dari perumusan peraturan yang dibuat secara demokratis oleh lembaga legislatif yang dipilih rakyat daripada oleh pejabat eksekutif yang ditunjuk Pemerintah. Lembaga legislatif daerah yang dipilih secara demokratis kemungkinan lebih bertanggung gugat dalam melakukan kegiatankegiatannya dibandingkan dengan lembaga eksekutif yang kebanyakan pejabatnya diangkat untuk jangka waktu yang panjang, yang umumnya pegawai negeri sipil (PNS) yang tidak bertanggung jawab secara langsung kepada rakyatnya (ADB, 2002b).

Dalam kaitannya dengan reformasi, pelaksanaan otonomi daerah diatur oleh Undang-Undang yang dibuat pada tahun 1999, yang memberikan kewenangan kepada Pemda untuk mengelola sumber daya hutannya sendiri dan memperoleh pendapatan dari sumber daya hutan tersebut. Hal ini merupakan suatu perubahan yang sangat besar setelah selama beberapa dekade ketentuan tersebut diatur oleh Pemerintah Pusat. Pemda kabupaten dan kotamadya di seluruh Indonesia menanggapi perubahan ini dengan sangat antusias melalui penyusunan Peraturan Daerah (Perda) baru mengenai pengelolaan kehutanan, meskipun banyak diantaranya tidak berpengalaman dalam membuat peraturan yang baru. Mereka menggunakan kewenangannya dalam berbagai cara dan menjalankan otonominya pada tingkat yang berbeda-beda (Simarmata 2003). Beberapa Perda baru memang turut memperkuat kebijakan konservasi sumber daya hutan, namun yang lainnya justru memberikan peluang terjadinya degradasi hutan yang lebih parah.

Disamping memperoleh kewenangan yang baru, Pemda juga mempunyai kewajiban dan tanggung jawab dalam menggunakan kewenangannya ini. Salah satu tanggung jawab tersebut adalah memastikan bahwa berbagai peraturan dan kebijakan yang mereka buat konsisten dengan Undang-Undang dan kebijakan yang dikeluarkan oleh Pemerintah Pusat. Meskipun otonomi daerah sudah berjalan, pada kenyataannya Undang-Undang Pemerintah Pusat masih tetap lebih diutamakan dibandingkan dengan Perda, khususnya dalam hal pengelolaan sumber daya alam (Undang-Undang 22/1999, Pasal 10). Pemda juga bertanggung jawab untuk menyusun Perda yang mengutamakan kepentingan masyarakat dan mengikuti prinsip-prinsip tata kelola pemerintahan yang baik (good governance), yang merujuk kepada tiga pilar utama, yaitu akses kepada informasi (transparansi), partisipasi, dan keadilan atau penegakan hukum (WRI, 2002).

Keberhasilan dan resiko pelaksanaan desentralisasi kehutanan akan bergantung kepada bagaimana Pemda mengartikan dan melaksanakan kewenangan dan tanggung jawabnya. Kunci untuk meningkatkan keberhasilan desentralisasi dan menyempurnakan kerangka hukum dan perundangundangannya adalah menyusun Perda yang bisa mengantisipasi (bukan mengabaikan) kenyataankenyataan yang ada dalam kehidupan masyarakat sehari-hari. Peraturan perundangan yang dibuat di masa lalu mengabaikan kenyataan adanya korupsi dan ketidaktaatan atas hukum yang berlaku dan dibuat seolah-olah peraturan tersebut akan benarbenar dilaksanakan dan ditegakkan (ADB, 2002b). Perda yang baru harus bisa mengatasi kenyataankenyataan seperti ini. Misalnya, jika di masa lalu ketidaktaatan terhadap berbagai peraturan terjadi di mana-mana, maka tidak realistis untuk mengharapkan Perda yang baru akan dipatuhi dengan lebih baik. Karena itu, untuk mendorong perilaku masyarakat dalam mematuhi peraturan, maka Perda tersebut harus mencakup tindakan-tindakan alternatif yang sifatnya sukarela, berbagai program 
insentif, atau pengakuan terhadap hukum adat. ${ }^{1}$ Demikian juga, jika lembaga-lembaga pemerintahan tidak bersikap transparan atau bertanggung-gugat, maka peraturan-peraturan baru mungkin tidak akan dilaksanakan sepenuhnya. Karena itu, Perda harus memungkinkan keterlibatan lembaga-lembaga pemeriksa independen atau memberdayakan LSM dan lembaga-lembaga adat untuk memastikan tanggunggugat dalam pengambilan kebijakan. Intinya, dengan menggunakan kewenangan legislatifnya, saat ini Pemda memiliki peluang untuk menjajaki cara-cara dan mekanisme baru untuk menjalankan tanggung jawab mereka yang baru ini.

Tulisan ini dimaksudkan sebagai pedoman bagi para pengambil keputusan. Tujuannya yang pertama adalah membantu pengambilan keputusan apakah tetap akan menyusun Perda baru; dan jika memang demikian, bagaimana melakukannya. Harus diketahui bahwa dalam banyak hal, setelah para pengambil keputusan mulai menganalisa isu-isu yang ada untuk menyusun Perda baru, mereka baru menyadari bahwa penyusunan Perda baru mungkin bukan tindakan yang terbaik. Mereka mungkin menyadari bahwa melaksanakan peraturan yang sudah ada dengan sepenuhnya akan merupakan tindakan yang lebih baik.

Yang kedua, apabila Perda baru dipandang sebagai tindakan yang terbaik, maka tulisan ini menyajikan pedoman bagi Pemda kabupaten dan kotamadya untuk menyusun Perda baru. Dalam pedoman ini yang pertama dijelaskan adalah tanggung jawab pokok Pemda kabupaten dan kotamadya. Selanjutnya, dijelaskan beberapa prinsip penting yang sebaiknya diterapkan dalam penyusunan Perda baru, dan mengidentifikasi beberapa mekanisme yang memungkinkan untuk melaksanakan prinsip-prinsip tersebut dan juga beberapa alternatif pelaksanaannya yang cukup mudah dan efektif. Pemda kabupaten atau kotamadya perlu didorong untuk mengembangkan berbagai alternatif tambahan yang mungkin lebih sesuai dengan kondisi dan situasi di kabupaten atau kotamadyanya masing-masing. Alternatif yang disajikan dalam pedoman ini bukan merupakan satu-satunya yang ada; namun hanya sekedar contoh saja. Selain itu, berbagai alternatif sebaiknya tidak dianggap saling terpisah satu sama lain. Sering gabungan beberapa alternatif merupakan kombinasi yang lebih baik, dan kadang-kadang sebagai pengganti mekanisme yang alternatifnya tidak ada. Pedoman ini dimaksudkan sebagai langkah awal bagi para pengambil kebijakan untuk merancang kebijakan yang menurut mereka paling sesuai.

Uraian dalam pedoman ini mungkin memberikan kesan seolah-olah hanya ada satu pendekatan dalam penyusunan Perda, namun sebenarnya tidaklah demikian. Penyusunan Perda merupakan proses yang hidup, dinamis, yang akan bervariasi antar yurisdiksi, antar daerah, antar subyek, dan antara individu pembuat kebijakan. Meskipun ada cara-cara yang lebih baik maupun lebih buruk, tidak ada satupun cara yang paling benar. Peraturan perundangan merupakan proses bukan sekedar sebuah produk. Bukan hanya sekedar isi peraturan perundangan, tetapi proses bagaimana peraturan itu diikuti, disusun, dikonsep, disosialisasikan, disahkan, dan akhirnya dilaksanakan dan ditegakkan. Penyusunan peraturan perundangan merupakan proses pengembangan gagasan tentang bagaimana Pemerintah dan masyarakat madani saling berinteraksi satu sama lain.

Pedoman ini juga diharapkan dapat digunakan sebagai panduan terutama bagi para pejabat Pemda, para wakil LSM, dan pihak-pihak lainnya yang terkait, khususnya di tingkat daerah. Penulis berharap pedoman ini dapat memberikan kontribusi berharga bagi para pembuat kebijakan dalam upaya mereka mereformasi kerangka hukum dan perundangundangan, baik di tingkat pusat maupun daerah, untuk mengelola hutan Indonesia secara lebih lestari.

\footnotetext{
${ }^{1}$ Adat secara harfiah diterjemahkan sebagai 'kebiasaan' atau 'tradisi.' Dalam konteks pemerintahan, istilah ini berarti sistem hukum atau kebiasaan adat atau tradisi yang mengatur kehidupan masyarakat terlepas dari peraturan-peraturan negara atau peraturan yang ada (ADB, 2002a; ICRAFdan JAPHAMA, 2000).
} 


\section{Kerangka Kerja Hukum dan Perundang-undangan Saat ini}

\section{A. Undang-Undang Otonomi Daerah}

Republik Indonesia telah melakukan upaya penting dalam desentralisasi kewenangan dari Pemerintah Pusat ke tingkat provinsi dan kabupaten/kotamadya. Upaya ini dilakukan melalui proses hukum yang berlangsung sangat cepat dan menakjubkan (Hofman dan Kaiser, 2002). Pada tahun 1999 dikeluarkan tiga Undang-Undang (UU) yang disahkan oleh Pemerintah Pusat untuk menjalankan proses ini, yaitu UU 22/ 1999 tentang Otonomi Daerah; UU 25/1999 tentang Perimbangan Keuangan antara Pemerintah Pusat dan Daerah dan UU 28/1999 tentang Korupsi, Kolusi, dan Nepotisme. $^{2}$

Undang-Undang 22/1999 merupakan sarana utama pelaksanaan desentralisasi. Tujuan UU 22/1999 secara keseluruhan, disebutkan dalam Pasal 4, yaitu untuk memberikan kewenangan kepada masyarakat di daerah untuk menyusun dan mengatur urusan daerahnya masing-masing, melalui keputusankeputusan yang mereka buat sendiri, dan didasarkan pada aspirasi-aspirasi yang juga berasal dari mereka sendiri. Di dalam pasal 7 ayat 1 disebutkan bahwa kewenangan ini meliputi semua urusan pemerintahan kecuali urusan luar negeri, pertahanan dan keamanan, kehakiman, keuangan, dan agama. Namun demikian, Pemerintah Pusat dapat mempertahankan kewenangan untuk urusan-urusan pemerintahan lainnya melalui berbagai PP. Selain itu, Pemerintah Pusat, menurut Pasal 7 ayat 2, tetap memiliki kewenangan untuk membuat kebijakan yang berkenaan dengan hal-hal tertentu seperti pemanfaatan sumber daya alam dan konservasi (Bell, 2001). Peran utama Pemerintah Pusat adalah memberikan petunjuk dan membuat berbagai standar, bukan mengendalikan secara langsung dan melakukan pengawasan dengan kebijakan khusus yang harus diikuti di tingkat daerah. Meskipun peran Pemerintah Pusat adalah menyediakan petunjuk, namun menurut pasal 7 UU 25/1999, Pemerintah Pusat masih berwenang untuk mengambil tindakan administratif terhadap Pemda yang gagal melaksanakan Undang-Undang atau peraturan yang ada. $^{3}$

Meskipun dorongan ke arah desentralisasi sangat kuat dan luas, menurut UU 22/1999, Pemerintah Pusat masih tetap memegang peranan yang menentukan terhadap Pemda. Di dalam Pasal 114 ayat 1 disebutkan bahwa Pemerintah Pusat dapat mencabut Perda yang bertentangan dengan kepentingan masyarakat luas atau PP yang lebih tinggi. Menurut Pasal 113, Pemda diwajibkan menyerahkan berbagai Perda baru yang disusunnya kepada Departemen Dalam Negeri, 15 hari setelah disahkan untuk dikaji ulang. Jika Perda tersebut kemudian dibatalkan oleh Menteri Dalam Negeri, maka Pemda harus mencabutnya. Namun menurut Pasal 115, apabila Pemda menolak untuk mencabut kembali Perdanya, maka masalah ini langsung diserahkan kepada Mahkamah Agung. Ketentuan ini masih belum banyak dilaksanakan karena Departemen Dalam Negeri kewalahan dengan tumpukan Perda baru yang diserahkan. Namun demikian, dalam beberapa bulan terakhir Menteri Dalam Negeri telah mencabut sejumlah Perda yang melanggar UU dan PP lainnya. Pada umumnya Perda yang banyak ditolak berkaitan dengan masalah pajak dan pungutan-pungutan yang tidak menunjang dunia usaha (Simarmata, 2003).

Peran Pemda provinsi terutama dalam hal koordinasi dan pengawasan. Di dalam pasal 9 UU 22/ 1999 dinyatakan bahwa Pemda provinsi memiliki kewenangan dalam tiga keadaan berikut: (1) kewenangan terhadap isu-isu yang ada dalam wilayah yang mencakup dua atau lebih wilayah kabupaten/ kotamadya; (2) kewenangan untuk menangani halhal yang belum atau tidak mampu ditangani oleh kabupaten/kotamadya; dan (3) kewenangan administratif yang diwakilkan oleh Pemerintah Pusat.

Dalam kaitannya dengan sumber daya alam, menurut pasal 10 ayat 1 UU 22/1999, Pemda diberi wewenang untuk mengelola sumber daya alam yang terdapat di dalam wilayahnya, dan bertanggung

\footnotetext{
2 Perhatikan istilah: 'Act' dalam versi bahasa Inggris digunakan secara khusus merujuk 'Undang-Undang', sementara 'Peraturan' merujuk pada ' $P P$ '. 'Law' dalam versi bahasa Inggris umum digunakan untuk menjelaskan 'Undang-Undang', tetapi ini tidak akurat, karena 'law' merupakan istilah umum yang diterjemahkan sebagai 'hukum'.

${ }^{3}$ Istilah 'Pemerintah daerah' digunakan untuk mencakup pemerintah tingkat kabupaten dan provinsi.
} 
jawab untuk 'menjaga lingkungan sesuai dengan Undang-Undang yang berlaku'. Ini berarti bahwa meskipun Pemda kabupaten dan kotamadya berwenang untuk melakukan pengelolaan lingkungan dan sumber daya alam yang ada di dalam wilayahnya, mereka harus melakukannya secara konsisten sesuai dengan peraturan perundangan yang dibuat oleh Pemerintah Pusat.

Jika UU 22/1999 merupakan sarana untuk pelaksanaan desentralisasi, maka UU 25/1999 adalah motornya. Undang-Undang ini menetapkan perubahan pengelolaan anggaran yang hampir menyeluruh dari Pemerintah Pusat ke Pemda. Undang-Undang 25/1999 menetapkan bahwa Pemerintah Pusat hanya menerima 20 persen dari total pendapatan sumber daya alam, khususnya kehutanan, perikanan, dan pertambangan; sementara Pemda memperoleh 80 persen. Dari jumlah yang diterima Pemda tersebut, 64 persen diserahkan kepada Pemda kabupaten/kotamadya dan 16 persen kepada Pemda provinsi (UU 25/1999 pasal 6 ayat 5, dan PP 104/2000 pasal 9-10). Untuk pendapatan Pemda kabupaten/kotamadya yang diterima dari sektor kehutanan, setengahnya dibagi sama rata diantara semua kabupaten/kotamadya, dan setengahnya lagi menjadi hak kabupaten/kotamadya tertentu yang melaksanakan kegiatan kehutanan. Dana Reboisasi, yaitu pendapatan yang berasal dari kegiatan penebangan hutan yang harus diinvestasikan kembali untuk pengelolaan sumber daya dan konservasi, sekarang 40 persen diserahkan kepada Pemda dan 60 persen diserahkan kepada Pemerintah Pusat. Undang-Undang 25/1999 dan berbagai peraturan lainnya juga telah meningkatkan wewenang Pemda kabupaten untuk mengenakan pajak terhadap berbagai kegiatan, barang dan orang.

Sementara keempat peraturan perundangundangan (UU 22/1999, UU 25/1999, PP 25/2000, dan PP 104/2000) merupakan intisari pelaksanaan desentralisasi, masih ada sekitar 1000 peraturan, keputusan, dan petunjuk lainnya yang diperkirakan sedang dalam proses modifikasi agar konsisten dengan keempat Undang-Undang pokok tersebut (GTZ, 2001). Namun masih banyak pertanyaan mengenai kewenangan di tingkat pusat dan provinsi dikaitkan dengan penekanan kewenangan yang berada di Pemda kabupaten/kotamadya. Isu utama yang saat ini harus dihadapi dalam rangka otonomi daerah adalah yang menyangkut fungsi yang harus dilakukan Pemda dan standar pelayanan minimal atau SPM (standar minimal yang harus dipenuhi Pemda kabupaten dan kotamadya tanpa memperhatikan bagaimana mereka menggunakan kewenangan barunya). Berbagai petunjuk untuk memenuhi berbagai kewajiban pokok dan standar minimum tersebut harus sesuai dengan PP 25/2000 pasal 2 ayat 4b. Namun masih terdapat banyak pertanyaan mengenai ruang lingkup yang sesuai untuk standar- standar ini. Apakah sebaiknya bersifat wajib dilaksanakan atau terserah kepada masing-masing Pemda, dan apakah standar-standar tersebut diberlakukan melalui insentif atau sanksi (Donor SMP Working Group, 2002; Patlis dkk., 2001). Pertanyaanpertanyaan lainnya menyangkut tingkat keterincian dan konsistensi standar-standar tersebut diantara berbagai sektor dan daerah. Baru-baru ini, Departemen Dalam Negeri melaksanakan dua kebijakan yang dikeluarkan tahun lalu, yang memberikan garis besar kerangka kerja untuk mengembangkan SPM (Departemen Dalam Negeri, 2002a dan 2002b).

\section{B. Undang-Undang Kehutanan}

Landasan hukum yang mengatur pengelolaan sumber daya hutan tertuang dalam Undang-Undang Kehutanan Nomor 41/1999 (UU 41/99), dan pelaksanaannya diatur dalam PP 34/2002. Walaupun UU ini telah menggantikan Undang-Undang Pokok Kehutanan (UUPK) tahun 1967 dan PP 6/1999, masih banyak ketidakjelasan mengenai pendelegasian kewenangan untuk peraturan yang berada di bawahnya. Meskipun telah banyak peraturan yang disahkan menurut UU 41/1999 dan peraturan-peraturan lainnya yang baru, namun peraturan-peraturan yang dibuat sebelum keluarnya UU 41/1999 masih tetap berlaku. Pasal 82 UU 41/1999 menjelaskan bahwa semua peraturan yang ada tetap berlaku sepanjang peraturan tersebut tidak bertentangan dengan Undang-Undang ini. Ketetapan ini mencerminkan kenyataan bahwa kerangka kerja hukum yang mengatur pengelolaan hutan masih merupakan peninggalan dari UUPK tahun 1997. Kehadiran PP 34/2002 lebih memperparah kesimpangsiuran ini: Pasal 100 dengan tegas mencabut PP 6/1999, tetapi Pasal 101 menyatakan bahwa semua Keputusan Menteri (KepMen) lainnya yang merupakan pelaksanaan PP 6/1999 tetap berlaku sepanjang KepMen tersebut tidak bertentangan dengan PP yang baru, dan sepanjang KepMen dimaksud tidak diubah atau dicabut oleh berbagai PP atau KepMen berikutnya. Cara pencabutan semacam ini telah menimbulkan banyak kerancuan dalam penafsiran hukum. Berbagai konflik yang disebabkan karena perbedaan penafsiran dan pelaksanaan kebijakan sering terjadi dan sulit diselesaikan.

Konflik-konflik yang muncul tersebut diperparah lagi oleh kenyataan bahwa UU 41/1999 dan PP 34/ 2002 dianggap berbau sentralistik, meskipun keduanya disahkan setelah berlakunya UU 22/1999 yang seharusnya dijadikan salah satu referensi bagi UU dan PP tersebut. Di dalam UU 41/1999 dinyatakan bahwa Pemerintah Pusat masih tetap memiliki tanggung jawab dalam menentukan status dan penataan kawasan hutan, melakukan inventarisasi dan perpetaan, dan menyiapkan rencana-rencana pengelolaan hutan. PP 34/2002 pasal 42 menjelaskan bahwa hanya Pemerintah Pusat yang berhak 
mengeluarkan izin penebangan kayu, berdasarkan rekomendasi dari Pemda. Hal ini merupakan perubahan yang signifikan dari berbagai PP dan KepMen mengenai kehutanan beberapa tahun terakhir ini. Perubahan ini juga telah memberi peluang dikeluarkannya berbagai izin oleh Pemda. Penjelasan PP 34/2002 menegaskan bahwa Menteri Kehutanan secara bertahap dan selektif akan mendelegasikan wewenang untuk mengeluarkan berbagai izin pemanfaatan kayu dari hutan produksi kepada Pemda. Tetapi dengan syarat bahwa Pemda yang bersangkutan dapat menunjukkan kesiapannya dalam hal kelembagaan, visi maupun misi. Namun demikian, tidak ada petunjuk lebih lanjut atau persyaratan khusus mengenai pelaksanaannya.

Kewenangan Pemda untuk mengambil berbagai keputusan dalam pengelolaan hutan, tidak banyak dibahas dalam UU 41/1999. Satu-satunya rujukan tentang kewenangan Pemda adalah dalam masalah pengawasan terhadap berbagai kegiatan di dalam hutan. Misalnya, Pasal 59-64 Bab VII UU 41/1999 menyatakan bahwa Pemerintah Pusat dan Pemda bertanggung jawab terhadap pengawasan hutan. Kemudian dalam Bab VIII Pasal 66 disebutkan bahwa Pemerintah Pusat dapat mendelegasikan kewenangan tertentu kepada Pemda untuk meningkatkan efisiensi administrasi pengelolaan hutan. Pada akhirnya peran Pemda hanyalah bersifat administratif, tanpa diberikan wewenang untuk mengambil keputusan yang berarti. PP 34/2002 juga mengikuti langkah kebijakan ini walaupun PP tersebut memberikan wewenang kepada Pemda untuk mengeluarkan berbagai izin di dalam wilayah yurisdiksinya. Kewenangan dimaksud diberikan untuk berbagai kegiatan yang tidak terkait dengan hasil hutan kayu, termasuk pemanfaatan kawasan, pemanfaatan jasa lingkungan, serta pemanfaatan dan pengumpulan hasil hutan bukan kayu (HHBK).

Kedudukan peraturan yang sentralistik ini disesuaikan dengan berbagai upaya yang ada saat ini (yang memberlakukan kembali hampir semua PP) untuk melakukan desentralisasi pengelolaan hutan. Pemerintah Pusat memberikan kewenangan kepada Pemda untuk mengeluarkan izin penebangan dan berbagai kegiatan kehutanan lainnya. Misalnya, PP No. 6/1999 yang sekarang diberlakukan kembali, memberikan kewenangan kepada Gubernur untuk mengeluarkan izin Hak Pengusahaan Hutan (HPH) untuk kawasan seluas 10.000 hektar dan memberikan kewenangan kepada Bupati untuk mengeluarkan izin Hak Pemungutan Hasil Hutan (HPHH) untuk kawasan yang luasnya sekitar 100 hektar. Kedua izin ini dikeluarkan untuk jangka waktu tidak lebih dari satu tahun. Izin-izin ini dikenakan Provisi Sumber Daya Hutan (PSDH) dan, jika izin ini berkaitan dengan penebangan, maka dikenakan Dana Reboisasi. KepMen No. 310/1999 yang sekarang juga diberlakukan kembali dan didasarkan pada PP 6/1999, menjelaskan bahwa izin HPHH untuk 100 hektar dapat dikeluarkan untuk hutan konversi atau hutan produksi dengan tujuan konversi atau guna penataan ulang. Namun demikian, KepMen tersebut secara khusus melarang pengeluaran izin HPHH untuk lahan-lahan yang telah berada dalam areal konsesi $\mathrm{HPH}$. Berdasarkan peraturan-peraturan ini, maka Pemda mengeluarkan istilah-istilah sendiri yang berkaitan dengan izin penebangan dan tidak perlu mengikuti persyaratan seperti yang tercantum dalam peraturan perundangan. Istilah-istilah tersebut termasuk IPK, IPPK, IPKH, IPKTM, IPHH, HPHKM, HPHH, dan HPH kecil. Upaya-upaya Departemen Kehutanan untuk melakukan desentralisasi pengelolaan hutan pada tingkat tertentu menimbulkan kesulitan untuk melakukan berbagai tindakan terhadap kebijakan Pemda, baik yang legal, semi-legal, maupun ilegal. Sementara upaya Pemerintah Pusat untuk mengeluarkan izin secara terpusat melalui UndangUndang baru, Pemda kabupaten dan kotamadya tidak senantiasa mengakuinya. Mereka bersikeras untuk tetap mengeluarkan izin sesuai dengan pemahaman mereka terhadap pasal-pasal yang tercantum dalam UU 22/1999.

Meskipun terjadi konflik-konflik akibat kesulitan sistematis dalam pemahaman kerangka kerja hukum yang mengatur pengelolaan sumber daya hutan, namun terdapat persyaratan-persyaratan yang sifatnya jelas dan tidak membingungkan (Patlis, 2002). Pada tahap perencanaan kehutanan, misalnya, langkah awal yang harus dilakukan oleh Departemen Kehutanan adalah menyiapkan Tata Guna Hutan Kesepakatan (TGHK) untuk masing-masing provinsi. Selanjutnya menyusun Rencana Pengukuhan dan Penatagunaan Hutan (RPPH), dengan menggunakan penataan dan tata batas kawasan hutan berdasarkan TGHK, yang dipaduserasikan dengan Rencana Tata Ruang Wilayah Propinsi (RTRWP). Kemudian dalam bidang pengusahaan hutan, pemohon HPH harus mengikuti persyaratan prosedural, substansial, dan finansial untuk memperoleh izin HPH-nya dan melakukan berbagai kegiatan pengelolaan hutan dalam areal konsesinya. Selanjutnya, perusahaan HPH harus melengkapi berbagai laporan, dua diantaranya yang paling penting adalah Laporan Hasil Cruising (LHC), yang meliputi informasi mengenai jumlah pohon, jenis, ukuran, dan volumenya berdasarkan hasil pengukuran blok tebangan. Dan yang kedua adalah Laporan Hasil Produksi (LHP), yang meliputi informasi mengenai jenis, ukuran, dan volume pohon yang sesungguhnya telah ditebang. Dalam bidang produksi, PP 34/2002, pasal 64 menjelaskan bahwa untuk pabrik penggergajian atau pabrik pengolahan kayu lainnya dengan kapasitas produksi sampai dengan 6.000 meter kubik per tahun, izinnya dikeluarkan oleh Gubernur, berdasarkan rekomendasi teknis dari Dinas Kehutanan kabupaten dan persetujuan dari Menteri Kehutanan. Untuk pabrik 
pengolahan kayu yang kapasitas produksinya lebih dari 6.000 meter kubik per tahun, harus memperoleh izin dari Menteri Kehutanan, berdasarkan rekomendasi Dinas Kehutanan provinsi atas nama Gubernur. Dalam kaitannya dengan transportasi, di dalam PP 34/2002, pasal 75 disebutkan bahwa semua hasil kayu harus memiliki Surat Keputusan Sahnya Hasil Hutan (SKSHH) dan Surat Asal-usul Tumbuhan dan Satwa Liar (SATS). Selanjutnya disyaratkan bahwa kondisi fisik, ukuran, tipe, jumlah, dan tujuan pengiriman produk kayu yang diangkut harus sesuai dengan syarat-syarat yang tercantum dalam dokumennya. Pedoman umum pengelolaan sumber daya hutan ini tidak menguraikan persyaratanpersyaratan tersebut secara rinci, tetapi Pemda kabupaten dan kotamadya seharusnya telah cukup mengetahui persyaratan-persyaratan ini. 


\section{Tanggung Jawab Pemerintah Daerah Kabupaten/Kotamadya}

Dalam era Desentralisasi, kabupaten dan kotamadya memiliki banyak tanggung jawab yang terkait dengan pengelolaan sumber daya alamnya, yang sebelumnya tidak pernah ada. Yang pertama, mengingat perubahan-perubahan yang terus berlangsung dalam pembangunan dan pelaksanaan Undang-Undang dan peraturan baru di semua tingkat pemerintahan, Pemda kabupaten dan kotamadya harus memelihara hubungan baik dengan Pemda provinsi dan Pemerintah Pusat untuk mengikuti perkembangan berbagai peraturan dan kebijakan baru. Selain itu, dengan terus mengikuti perkembangan informasi, mereka dapat turut memberikan masukannya dalam penyusunan peraturan dan kebijakan baru serta perubahan-perubahan yang mungkin akan dilakukan dengan lebih baik. Ada beberapa asosiasi yang barubaru ini terbentuk untuk mewakili badan-badan pemerintahan di daerah. Asosiasi Pemerintah Kabupaten Seluruh Indonesia (APKASI), misalnya, mewakili Pemda kabupaten secara administratif; Asosiasi Dewan Kabupaten Seluruh Indonesia (ADKASI) mewakili dewan legislatif kabupaten. Pemda kotamadya juga memiliki asosiasi untuk badan-badan administratif, yaitu Asosiasi Pemerintah Kota Seluruh Indonesia (APEKSI), dan asosiasi untuk badan legislatif, yaitu Asosiasi Dewan Kota Seluruh Indonesia (ADEKSI). Dalam lingkup Pemda provinsi juga terdapat dua kelompok. Yang pertama untuk badan administratif, yaitu Asosiasi Pemerintah Provinsi Seluruh Indonesia (APPSI), dan yang kedua untuk badan legislatif, yaitu Asosiasi Dewan Provinsi Seluruh Indonesia (APDSI). Berbagai kabupaten dan kotamadya juga dapat membentuk kelompokkelompok regional yang memiliki kepentingan geografis atau sektoral yang serupa untuk saling berbagi informasi dan mengembangkan posisi mereka.

Yang kedua, Pemda kabupaten dan kotamadya harus melakukan upaya untuk mempelajari status Undang-Undang yang saat ini masih berlaku dan harus mereka laksanakan. Dalam kaitannya dengan sumber daya hutan, Pasal 10 ayat 1 UU 22/1999 menetapkan bahwa Pemda diberi kewenangan untuk mengelola sumber daya alam yang terdapat di wilayahnya dan bertanggung jawab untuk 'menjaga lingkungan dan pelestariannya sesuai dengan Undang-Undang'. Persyaratan ini sudah sangat jelas. Undang-Undang tentang lingkungan yang ada sebelumnya tetap berlaku sesuai UU 22/1999, tetapi sekarang harus dilaksanakan oleh kabupaten dan kotamadya dan bukan lagi oleh Pemerintah Pusat. Karena itu kabupaten/kotamadya bertanggung jawab untuk mengetahui dan memahami syarat-syarat yang disebutkan dalam Undang-Undang tersebut, termasuk juga yang berkaitan dengan sumber daya alam dan keanekaragaman hayati, pengelolaan lingkungan, pertambangan, perikanan, kehutanan, perairan, dan syarat-syarat untuk melakukan Analisis Dampak Lingkungan (AMDAL). Selain itu kabupaten/ kotamadya juga bertanggung jawab untuk melaksanakan dan menegakkan Undang-Undang tersebut.

Keterbatasan informasi mengenai Undang-Undang yang ada di tingkat Pemda diperparah oleh kenyataan bahwa Pemda kabupaten dan kotamadya menjalankan kewenangan mereka tanpa petunjuk dan alasan yang jelas, dan kadang-kadang, tanpa memperhatikan Undang-Undang dan Peraturan yang berlaku (Simarmata, 2003). Misalnya, di Malinau Kalimantan Timur, dalam waktu 11 bulan dua Bupati berturut-turut mengeluarkan 39 Izin Pemungutan dan Pemanfaatan Kayu (IPPK) yang luas totalnya hampir mencapai 56.000 hektar untuk HPH-HPH kecil (Barr dkk., 2001). Meskipun peraturan yang ada membatasi luas HPH-HPH ini hanya 100 hektar, Malinau mengeluarkan izin sampai seluas 5.000 hektar. Selain itu, banyak IPPK mengizinkan kegiatan tebang habis, yang sebenarnya dilarang oleh Undang-Undang. Mereka juga mengizinkan penangkapan jenis-jenis satwa liar yang terancam punah yang sesungguhnya dilindungi oleh Undang-Undang. Di dalam IPPK juga tidak dicantumkan berbagai persyaratan yang diharuskan dalam kaitannya dengan perencanaan, pemantauan, dan pelaporan lingkungan (Mariasa, 2001 komunikasi pribadi).

Contoh lain yang jelas-jelas merupakan kegiatan ilegal dan dilakukan oleh beberapa kabupaten adalah pemungutan pajak atau retribusi untuk pengangkutan kayu ilegal yang melewati wilayah kewenangannya. Kegiatan ini, yang berlangsung di Kalimantan Timur 
dan Tengah, kadang-kadang dilaksanakan secara sistematis (Casson, 2001), dan kadang-kadang tidak sistematis (McCarthy, 2001). Kabupaten dan kotamadya sesungguhnya berkewajiban menyita kayu-kayu ilegal yang tidak memiliki kelengkapan administrasi dan tidak ada tanda asal usulnya. Namun dalam kasus ini, mereka tidak menyita kayu ilegal tersebut, tetapi malah mengenakan pungutan sebagai pajak angkutan dan mengizinkan kayu tersebut keluar dari wilayahnya. Dengan cara seperti ini, kabupaten secara terang-terangan telah ikut serta melegalkan kayu yang asal usulnya tidak jelas. Pungutan semacam ini tidak sah karena kabupaten mengizinkan pengangkutan kayu ilegal, yang menurut UndangUndang tidak dapat dibenarkan. Perlu dicatat bahwa pungutan-pungutan ini tidak berarti 'melegalkan' kayu-kayu yang ditebang secara ilegal, dan pemenuhan persyaratan peraturan daerah atau pusat sesudah itu tidak mengubah status kayu ilegal tersebut. Sebaliknya, pungutan-pungutan ini justru membuktikan bahwa kayu tersebut telah ditebang secara ilegal. Pemda kabupaten dan kotamadya harus menyadari implikasi kegiatan-kegiatan seperti ini.

Ketiga, Pemda kabupaten dan kotamadya harus menyusun perencanaan anggaran dan ketrampilan dalam pengelolaannya. Karena sebagian besar sumber penghasilan baru dari kabupaten atau kotamadya berasal dari pemanfaatan sumber daya alam, distribusi pendapatan satu daerah dengan daerah lainnya akan berbeda jauh sekali (Brown, 1999). Yang lebih penting lagi, sebagian besar penghasilan digunakan untuk membiayai kegiatan administratif dan bukan untuk kegiatan atau program pembangunan yang terencana. Dengan demikian, kabupaten/kotamadya sering hanya memiliki pendapatan baru yang sangat kecil untuk melaksanakan proyek-proyek pembangunan dan konservasi sumber daya, kecuali jika kabupaten/ kotamadya mulai mengumpulkan pendapatan asli daerah (PAD) dalam bentuk pajak, atau dengan mengeksploitasi sumber daya alamnya. Banyak sekali Perda yang berkaitan dengan PAD dan transparansi pelaporannya yang disahkan baru-baru ini, tetapi Perda itu sendiri tidak memberikan kemampuan kepada kabupaten/kotamadya untuk melakukan perencanaan dan pengelolaan anggaran.

Keempat, dan mungkin ini yang terpenting, Pemda kabupaten dan kotamadya perlu mengembangkan ketrampilan baru dalam merancang Perda. Rancangan yang buruk merupakan fenomena umum di Indonesia. Rancangan peraturan ini kemungkinan memang disengaja, untuk memberi kesempatan agar sistem korupsi, kolusi dan nepotisme tetap bertahan (ADB, 2002b), atau memang terjadi karena Pemerintah tidak melakukan latihan dan tidak memiliki infrastruktur untuk merancang peraturan yang baik
(Seidman dkk., 2001). Kemauan politik yang lemah biasanya menjadi penyebab rancangan peraturan yang sengaja dibuat buruk, dan terjadinya hal ini biasanya juga dikarenakan keterbatasan sumber daya (meskipun ini juga mungkin mencerminkan kemauan politik yang lemah untuk mendapatkan sumber daya).

Pada saat ini, banyak Pemda kabupaten menjalankan kewenangannya dengan cara-cara yang sebenarnya malah mempercepat kegiatan penebangan, dan memperburuk berbagai konflik para pihak yang berkepentingan, khususnya yang berkenaan dengan tuntutan hak kepemilikan lahan (ITTO, 2001). Di Sumatra dan Kalimantan, banyak Pemda kabupaten mengeluarkan berbagai izin atas lahan pedesaan, dan di areal yang sebelumnya telah diberikan kepada HPH. Di Kalimantan Timur, keterbatasan peta dan inventarisasi lahan memperburuk perselisihan batas wilayah yang terjadi antar IPPK, antar HPH, dan antara masyarakat desa dan masyarakat adat (Tim CIFOR di Long Loreh 2001, kom.pri). Para pihak yang berkepentingan tidak memiliki pemahaman yang jelas tentang di mana kegiatan-kegiatan legal dapat dilakukan atau siapa yang memiliki kewenangan yang sah untuk melakukan kegiatan tertentu; tidak jelas pula hak-hak siapa yang lebih kuat dan siapa yang tidak. Masalah-masalah yang muncul dari rancangan peraturan yang buruk menjadi semakin rumit karena Desentralisasi tidak hanya menghadirkan kewenangan baru bagi kabupaten, tetapi juga bagi Pemda kabupaten baru. Jumlah kabupaten di Indonesia meningkat lebih dari 25 persen mulai tahun 1999 hingga sekarang. Pemda kabupaten yang baru membutuhkan pelatihan dan bantuan untuk menyusun berbagai Perda yang sesuai dengan wilayah yurisdiksi mereka.

Tanpa pelatihan dan kemampuan yang memadai, para anggota Dewan Legislatif barangkali akan memperburuk masalah-masalah yang sudah ada. Sebuah peraturan baru yang dirancang dengan tergesa-gesa dapat menambah rumit masalah jika peraturan tersebut membingungkan, tidak jelas, terlalu umum dan tidak bisa dijalankan. Dalam era Desentralisasi, anggota Dewan Legislatif di kabupaten dan kotamadya bisa mengesahkan sebuah Perda hanya dalam waktu beberapa minggu saja. ${ }^{4}$ Tahun 2002, misalnya, Kabupaten Malinau mengesahkan enam buah Perda yang berkaitan dengan masalah struktur dan administrasi pemerintahan tingkat desa, adat, pemanfaatan hutan, dan retribusi untuk mendirikan bangunan. Hampir semua isi Perda tersebut dapat dikatakan disalin kata demi kata dari Kabupaten Bulungan, tetangganya; dan sama sekali mengabaikan sifat-sifat dan ciri-ciri unik dari kehidupan masyarakat dan keadaan hutan di Malinau. Padahal tidak seperti Bulungan, Malinau memiliki jumlah penduduk yang lebih tinggi dan tersebar di

4 'Peraturan daerah,' atau Perda, merupakan peraturan yang disahkan oleh pemerintah daerah (Pemda) provinsi atau kabupaten. 
beberapa kabupaten dengan jumlah suku yang sangat bervariasi, diantaranya, suku Punan yang seminomadik. Kondisi hutan Malinau juga relatif lebih baik dan asli (Tim CIFOR di Long Loreh 2001). Kenyataan bahwa banyak Perda baru yang tidak memperhitungkan karakteristik penduduk ini mungkin pada akhirnya akan memperburuk masalah di Kabupaten Malinau karena kelompok-kelompok tertentu akan terpinggirkan. Pengeluaran IPPK yang berlangsung dengan amat cepat, dapat menimbulkan pergolakan sosial, kebingungan dalam penentuan batas wilayah, dan pada gilirannya menguras sumber daya yang menjadi basis kegiatan mereka.

Dalam melaksanakan kewenangan barunya dalam bidang pengelolaan sumber daya alam, Pemda kabupaten dan kotamadya bertanggung jawab untuk menyusun Perda guna mengelola sumber daya alam secara lestari, untuk generasi sekarang dan yang akan datang, dan secara berkeadilan bagi semua pengguna sumber daya alam tersebut. Banyak hasil studi mengungkapkan bahwa penerapan prinsip-prinsip tata kelola pemerintahan yang baik sebagai dasar untuk penyusunan kerangka kerja hukum dan perundang-undangan tingkat nasional maupun wilayah merupakan faktor yang penting dalam mencapai pengelolaan sumber daya alam yang berkelanjutan (Smith dan Martin, 2000). Perbaikan kerangka kerja hukum tidak terbatas hanya dalam hal perumusan rancangan peraturan yang sesuai saja. Kerangka ini juga meliputi berbagai fungsi administrasi, penegakan hukum, dan penyelesaian masalah secara adil. Menurut Bank Pembangunan Asia, empat kegiatan yang penting untuk meningkatkan kerangka kerja hukum adalah: memperbaiki proses penyiapan peraturan dengan melakukan penilaian dampaknya secara rutin; melakukan cara-cara konsultasi yang efektif baik di dalam maupun di luar lingkup pemerintahan; memperkuat lembaga-lembaga eksternal untuk meningkatkan tanggung gugat; dan memperkuat kemampuan lembaga peradilan untuk memecahkan berbagai masalah administratif (ADB, 2002b). Bagianbagian berikut dalam tulisan ini akan membahas isuisu tersebut yang terkait dengan prinsip-prinsip 'tata kelola pemerintahan yang baik dan bertanggung jawab.' 


\section{Prinsip-prinsip Penyusunan Peraturan Daerah Tentang Kehutanan}

Sebelum menyusun Perda baru tentang pengelolaan hutan, Pemda harus benar-benar memahami wewenang dan tanggung jawabnya. Selain itu mereka juga perlu memahami dengan jelas kerangka kerja hukum dan perundang-undangan yang ada dan mempertimbangkan apakah sebuah Perda memang paling sesuai untuk memecahkan masalah yang sedang dihadapi atau tidak.

Pemerintah Pusat telah memberikan petunjuk mengenai beberapa kewenangan dan tanggung jawab Pemda. Namun ada kewenangan lainnya yang mungkin lebih berarti tetapi justru tidak terlalu jelas, yaitu yang terkait dengan prinsip-prinsip 'tata kelola yang baik dan bertanggung jawab' atau ‘goodgovernance'. Governance didefinisikan sebagai proses pengambilan keputusan yang melibatkan seluruh pihak yang berkepentingan. Good governance memiliki beberapa ciri yang seluruhnya menunjang proses pengambilan keputusan tersebut. Komisi Sosial dan Ekonomi PBB untuk Asia dan Pasifik atau United Nations Economic and Social Commission for Asia and the Pacific (UNESCAP) menjelaskan ciriciri good governance sebagai berikut:

[Good governance] bersifat partisipatif, berorientasi pada konsensus, bertanggung gugat, transparan, responsif, efektif dan efisien, adil dan inklusif serta sesuai peraturan perundang-undangan. Good governance menjamin bahwa korupsi ditekan sekecil mungkin, pendapat-pendapat kelompok minoritas dipertimbangkan dan suara-suara dari golongan masyarakat paling bawah didengar dalam pengambilan keputusan. Good governance juga bersifat responsif terhadap berbagai kebutuhan masyarakat di masa kini dan mendatang. (UNESCAP, 2002)

Identifikasi dan penjelasan mengenai good governance banyak dijumpai dalam beberapa pustaka. Para pakar dan kelompok advokasi meringkasnya menjadi tiga pilar: informasi (transparansi), partisipasi, dan akses terhadap keadilan (penegakan hukum) (WRI, 2002). Adapun ketiga pilar ini sangat dipengaruhi oleh sistem hukum dan perundang-undangan yang berfungsi dengan baik; pelaksanaan good governance harus terkoordinasi dan keputusannya terintegrasi, memiliki tanggung jawab terhadap anggaran, memiliki kejelasan, memiliki kepastian hukum yang seimbang dengan fleksibilitas administratif, validitas ilmiah yang seimbang dengan berbagai pertimbangan sosial-ekonomi, dll. Namun, bagaimana prinsipprinsip ini bisa dilaksanakan di lapangan tidak banyak dibahas dalam pustaka (Botchway, 2001). Beberapa pakar mulai mengidentifikasi dan mendalami prinsipprinsip ini. Misalnya, Organisasi Pangan dan Pertanian Sedunia atau Food and Agricultural Organisation, menetapkan enam prinsip untuk merancang UndangUndang Kehutanan yang lebih baik: (1) menghindari agar tidak melampaui batas kewenangan legislatif yang ditentukan; (2) menghindari persyaratan yang berlebihan untuk mendapatkan izin dan persetujuan; (3) meningkatkan ketentuan-ketentuan yang bersifat transparan dan bertanggung gugat; (4) meningkatkan peran LSM; (5) memastikan bahwa rancangan peraturan perundangan bersifat partisipatif; dan (6) memastikan bahwa Undang-Undang tersebut mencakup mekanisme penegakkannya secara langsung (Lindsay, 2002).

Prinsip-prinsip tata kelola yang baik dan bertanggung jawab -menurut definisi mana punmemenuhi tiga unsur persyaratan yang diperlukannya, yaitu proses, substansi, dan keadilan (lihat Gambar 1). Proses, berkaitan dengan mekanisme pembuatan peraturan perundanganbagaimana cara perumusan dan pengambilan keputusannya dan bagaimana pelaksanaanya. Mekanisme-mekanisme ini meliputi aspek-aspek transparansi, partisipasi, koordinasi, integrasi, tanggung gugat, penegakkannya, kejelasan, dan kelangsungan anggarannya. Substansi, terkait dengan isi peraturan-apa yang diatur di dalamnya dan apa alasannya. Sifat-sifat substansi ini meliputi kepastian hukum, fleksibilitas administratif, validitas ilmiah, dan pertimbangan sosial-ekonomi. Keadilan, berkaitan dengan penerapan peraturan-siapa yang terkena peraturan dan bagaimana peraturan itu ditegakkan. Penerapan tentang keadilan meliputi akses terhadap keputusan pengadilan, proses pemeriksaan, dan dengar pendapat yang adil. 
Gambar 1. Prinsip-prinsip untuk Merancang Peraturan Daerah

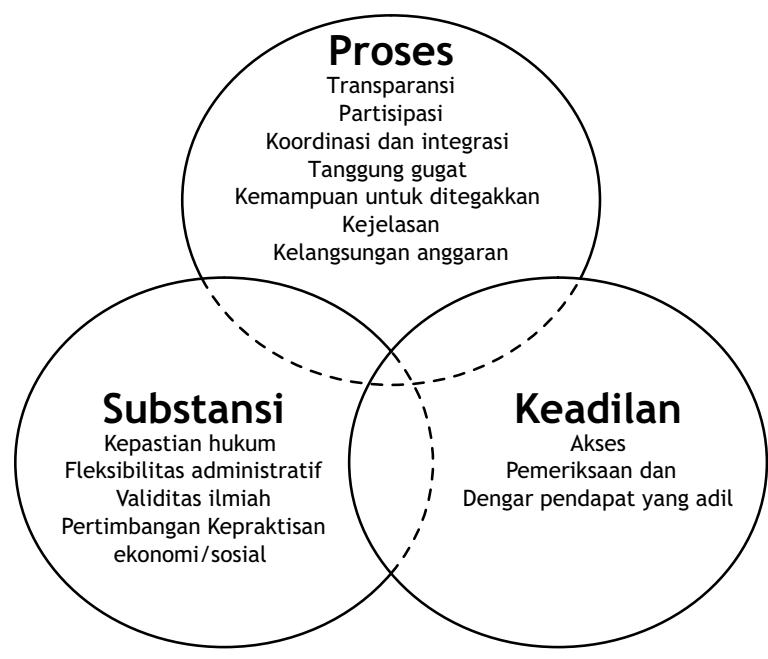

Dalam mempertimbangkan prinsip-prinsip tata kelola yang baik, ada dua hal yang sangat penting. Pertama, prinsip-prinsip ini bertujuan untuk menciptakan sistem hukum yang berkaitan langsung dengan masyarakat yang diaturnya-sistem hukum yang didasarkan atas kebutuhan, keinginan, dan kemampuan masyarakat. Prinsip-prinsip ini tidak bisa terlalu normatif atau aspiratif karena jika demikian akan tidak realistis dan tidak bisa dilaksanakan. Kedua, prinsip-prinsip ini didasarkan pada persyaratan bahwa masyarakat dilibatkan dalam penyusunan, pengenalan, dan pemahaman sistem hukum mereka. Tujuannya untuk meningkatkan pelaksanaan, penataan, dan penegakkannya (Lindsay, 2000). Artinya, Undang-Undang tidak hanya mencerminkan kepemimpinan pemerintahan suatu negara atau instansi, tetapi juga mencerminkan masyarakat secara umum. Seperti yang dikatakan Lindsay (2000), rekomendasi untuk memulai proses pembuatan peraturan 'tidak hanya karena didasarkan kepada keyakinan bahwa masyarakat harus memiliki hak untuk dilibatkan; tetapi merupakan suatu pengakuan pragmatis bahwa tanpa keterlibatan masyarakat, suatu peraturan perundangan menjadi lemah dalam pelaksanaannya.

Dalam menyusun Perda baru, Pemda tidak hanya perlu memasukkan pernyataan yang mengakui prinsip-prinsip tata kelola yang baik -yang biasanya mereka lakukan-tetapi mereka harus menggunakan bahasa yang jelas dan spesifik tentang bagaimana melaksanakan prinsip-prinsip tersebut. Bagian berikut ini membahas beberapa prinsip tata kelola yang baik dan bagaimana pelaksanaannya di kabupaten atau kotamadya yang memiliki sumber daya yang terbatas.

\section{A. Transparansi}

Proses yang transparan memungkinkan masyarakat memperoleh informasi tentang Perda yang akan berdampak kepada mereka. Selain itu, proses transparansi juga memberikan peluang bagi masyarakat untuk memantau Pemda dan memastikan bahwa Perda yang disusun sesuai dengan UndangUndang-pengawasan terhadap kinerja Pemda. Transparansi mengharuskan masyarakat untuk mengetahui berbagai kejadian, surat-surat keputusan penting, dan kebijakan-kebijakan yang akan dibuat oleh Pemda. Agar masyarakat memperoleh informasi seperti ini, maka setiap langkah dalam proses penyusunan Perda harus diinformasikan kepada masyarakat. Misalnya, untuk mengeluarkan suatu izin, masyarakat harus diberitahu tentang pengajuan izin awal, rancangan Perda yang disertai data dan berbagai laporan yang mendukung Perda itu, keputusan akhir dan berbagai alasan yang menyusun Perda harus diganti, dan membuka peluang yang memungkinkan untuk peninjauan kembali atas Perda yang ada. Transparansi akan meningkatkan hubungan antara Pemda dan masyarakat sehingga pertukaran informasi dan pengambilan keputusan melibatkan kedua pihak ini (Tendler, 1997).

Transparansi bukan hanya sekedar menyebarluaskan pengetahuan dan menyampaikan pemberitahuan, tetapi memerlukan penjelasan dan diskusi. Tanpa diskusi, masyarakat mungkin tidak memahami arti Perda yang sedang disusun, atau berbagai dampak yang akan diterimanya. Para pejabat di kabupaten perlu menjelaskan rencana penyusunan Perda tersebut jika menghendaki prosesnya transparan. Beberapa alternatif berikut merupakan pilihan untuk mewujudkan transparansi:

Alternatif A: Menyediakan berbagai surat keputusan dan kebijakan Pemda di tempattempat umum. Dokumen-dokumen ini harus disertai data dan informasi yang melatarbelakanginya -Undang-Undang, laporan, survei, data ekonomi, dll.-yang mungkin digunakan dalam menyusun Perda. Sebuah pusat informasi atau ruang baca tersendiri dapat disediakan di berbagai kantor Pemda. Alternatif ini mudah dan tidak membutuhkan banyak biaya, tetapi sulit untuk menjangkau sebagian besar masyarakat, yang mungkin tidak dapat melakukan perjalanan jauh ke kantor-kantor Pemda secara berkala.

Alternatif B: Mempublikasikan dan menyebarluaskan berbagai pengumuman, dokumen, dan keputusan. Pengumuman bisa dimuat dalam koran-koran lokal, selebaran, brosur, papan pengumuman, dll. Misalnya, di desadesa, berbagai berita dari Camat dan Bupati sering disampaikan ke rumah Kepala Desa, sekolah, atau tempat umum lainnya di desa. Pengumuman seperti ini sebaiknya disebarluaskan untuk setiap tahap dalam proses pembuatan Perda. Pengumuman tersebut juga bisa meliputi 
pemberitahuan tentang dimana dan bagaimana cara untuk memperoleh informasi dan berbagai keputusan-keputusan penting lainnya.

\begin{abstract}
Alternatif C: Melakukan pertemuan berkala yang terbuka untuk umum. Berbagai pertemuan dapat diadakan di salah satu tempat seperti kantor pemerintah yang berwenang untuk membuat Perda, atau di tempat lain seperti di desa-desa di wilayah pemerintahan yang akan terkena dampak oleh Perda. Metode ini membutuhkan banyak biaya, tetapi merupakan cara pemberitahuan yang paling efektif. Pertemuanpertemuan ini harus dihadiri oleh para pejabat pemerintah untuk dapat menjawab berbagai pertanyaan dan memberikan penjelasan lebih lanjut. Agar pertemuan ini mencapai sasaran yang diharapkan, maka tempat pertemuan harus mudah didatangi dan dipublikasikan sebelumnya.
\end{abstract}

Alternatif $D$ : Membangun siaran radio. Ini merupakan cara pemberitahuan yang paling efisien di berbagai kabupaten yang wilayah kewenangannya luas dan penduduknya sedikit, khususnya jika infrastruktur transportasi belum berkembang dengan baik. Biaya-biaya yang harus dikeluarkan untuk perlengkapan siaran radio dan frekuensi penerimaannya mungkin tinggi, tetapi biaya pemeliharaannya tidak terlalu mahal, sementara akses untuk bisa mendengarkan radio selalu ada. Pemda dapat mengatur jadwal siaran yang terkait dengan berbagai kegiatan dan kebijakan. Sistem Hutan Kemasyarakatan, sebuah instansi swadaya masyarakat yang berbasis di Samarinda dan bekerja di Kutai Barat, mengusulkan untuk membuat jaringan radio yang siarannya bisa ditangkap di desa-desa terpencil sehingga mereka dapat memperoleh akses kepada informasi dan komunikasi.

Alternatif E: Memenuhi permintaan individu: Hal ini menyangkut kemudahan dalam memenuhi permohonan individu untuk memperoleh suratsurat keputusan tertentu dari Pemda, dan kewajiban Pemda untuk menyediakan surat yang diminta dengan baik dan cepat. Memenuhi permintaan individu semacam ini dilakukan sebagai tambahan dalam memberikan pelayanan informasi kepada masyarakat.

\section{B. Partisipasi}

Partisipasi masyarakat merupakan tahapan setelah penyebar luasan informasi. Setelah masyarakat memperoleh pemberitahuan tentang suatu masalah yang terkait dengan sebuah Perda, bagaimana masyarakat tersebut kemudian bisa berpartisipasi dalam proses penyusunan Perda? Partisipasi memungkinkan masyarakat untuk ikut terlibat, memiliki informasi yang cukup, dan lalu memahaminya, sehingga mereka dapat mengerti proses pengambilan keputusan yang dilakukan oleh Pemda. Partisipasi masyarakat juga memungkinkan Pemda memperoleh informasi yang lebih baik dari masyarakat sehingga timbul gagasan baru dari Pemda, dan menambah pemahaman masyarakat secara menyeluruh terhadap suatu masalah (Axelrod 1984). Partisipasi, lebih jauh membantu mengurangi kemungkinan berbagai konflik dalam melaksanakan Perda karena berbagai isu yang mungkin memicu konflik telah diumumkan dari awal sehingga konflik bisa ditekan selama proses pengambilan keputusan (Ostrom, 1992). Akhirnya, partisipasi merupakan suatu bentuk tanggung gugat, yang memberikan kesempatan kepada masyarakat untuk mengawasi apa yang sedang dikerjakan pemerintah (Estache, 1995).

Ada banyak sekali definisi tentang partisipasi masyarakat, tetapi pada intinya menghendaki keterlibatan masyarakat secara berarti dalam membuat suatu keputusan (WRI, 2002). Partisipasi bisa berupa sekedar menerima informasi konsultasi dan kemitraan, sampai kepada kontrol sepenuhnya oleh masyarakat dalam pengambilan keputusan (Arnstein, 1969). Berbagai kondisi dapat menentukan tingkat keterlibatan apa saja yang 'berarti', seperti tingkat keterlibatan yang ada sebelumnya; siapa dan apa yang akan dipengaruhi oleh Perda; untuk berapa lama Perda tersebut akan berlaku; dll.

Aturan hukum setempat sering menyebutkan perlunya proses yang bersifat 'terbuka dan demokratis', atau melibatkan 'partisipasi masyarakat', tetapi tidak menjelaskan apa arti istilah-istilah ini secara praktis. Pada umumnya, 'pemberitahuan dan tanggapan' mengharuskan adanya tiga hal: (1) kesempatan untuk mengkaji rancangan peraturan dan berbagai dokumen yang melatarbelakanginya; (2) peluang untuk memberikan tanggapan terhadap substansinya; dan (3) tanggapan pembuat kebijakan terhadap komentar-komentar yang mereka terima. 'Pemberitahuan dan tanggapan' membutuhkan forum tertentu -tatap muka, atau tertulis, atau beberapa cara komunikasi lainnya sehingga masyarakat dapat menyampaikan berbagai komentar, dan pemerintah perlu menanggapi substansinya dengan cepat.

Namun demikian, untuk menciptakan partisipasi yang berarti di daerah lebih banyak lagi yang perlu dilakukan. Pejabat-pejabat yang mewakili Pemda perlu mengunjungi desa-desa yang akan terkena dampak akibat keluarnya Perda baru, mengadakan tatap muka dengan instansi-instansi di tingkat desa, dan mengadakan dialog dengan masyarakat untuk memungkinkan mereka memperoleh akses informasi. Kesempatan pertemuan seperti ini harus dijadikan peluang bagi masyarakat untuk mengungkapkan pendapatnya, bukan hanya bagi pemerintah saja yang memberitahukan rencananya. Sebuah pertemuan 
dimana para pejabat Pemda memberikan presentasi - sering disebut 'sosialisasi' - mungkin sudah cukup untuk mencapai suatu tingkat transparansi (meskipun untuk ini, agar masyarakat lebih memahami isinya, mereka harus diberi peluang untuk mengajukan pertanyaan dan mendapatkan jawaban), tetapi tidak cukup untuk mencapai arti partisipasi yang sebenarnya. Selain itu, berbagai pertemuan semacam ini harus bisa dihadiri masyarakat, dipublikasikan sebelumnya, dan hasilnya harus didokumentasikan agar bermanfaat dikemudian hari.

Yang terakhir, partisipasi yang ideal memerlukan negosiasi diantara berbagai kelompok dan anggota masyarakat yang berbeda kepentingannya dengan Pemda. Proses ini akan memberikan kesempatan kepada para anggota komisi non-pemerintah yang mewakili masyarakat untuk bersama-sama wakil Pemda menyusun dan menegosiasikan isi Perda. Cara ini dapat dilakukan secara mendadak sesuai kebutuhan atau bisa juga secara berkala, dengan para anggota komisi secara bergiliran.

Alternatif A: Menggunakan pemberitahuan dan tanggapan: Berbagai cara pemberitahuan dan tanggapan dapat digabungkan sebagaimana pilihan alternatif untuk menciptakan transparansi. $\mathrm{Hal}$ ini termasuk penyebarluasan pengumuman, pertemuan dengan masyarakat, dan pemberitahuan melalui siaran radio. Pemberitahuan akan mengundang masyarakat untuk memberikan tanggapan atas rancangan Perda selama jangka waktu tertentu. Tiga puluh hari biasanya dianggap cukup untuk menyebarkan pemberitahuan dan mendapatkan tanggapan (WRI 2002), tetapi hal ini benar-benar tergantung pada keadaan. Sebuah kabupaten yang luas dengan sarana komunikasi yang terbatas mungkin membutuhkan waktu yang jauh lebih lama. Berbagai komentar mungkin disampaikan secara tertulis atau lisan, tetapi risalah atau notulen berbagai pertemuan harus disimpan, dan prosesprosesnya harus didokumentasikan.

Alternatif B: Membentuk dewan penasihat. Pemda dapat mengizinkan dan menyetujui pembentukan komisi atau dewan-dewan penasehat yang para anggotanya bukan merupakan pejabat pemerintah, untuk bersamasama menyusun dan menegosiasikan isi Perda. Ini dapat dilakukan secara ad-hoc sesuai kebutuhan atau dengan mengadakan pertemuan secara berkala secara bergilir diantara pihak-pihak yang berkepentingan yang berbeda. Pembentukan komisi-komisi seperti ini bukan untuk menggantikan proses pemberitahuan dan komentar, melainkan sebagai tambahan agar proses partisipasi masyarakat menjadi lebih terarah.
Alternatif C: Mengadakan konsultasi terbuka dengan masyarakat. Pemda dapat melakukan negosiasi berbagai kebijakan secara langsung dengan anggota-anggota masyarakat. Proses ini tentu saja paling diinginkan, tetapi paling sulit untuk dilaksanakan. Namun, pertemuanpertemuan khusus mungkin dapat diatur untuk melakukan negosiasi berbagai kebijakan dan rancangan Perda dengan para pemuka masyarakat.

\section{Koordinasi dan Integrasi}

Koordinasi dan integrasi berkaitan dengan hubungan timbal balik diantara instansi-instansi pemerintah dan memungkinkan pengambil keputusan pada suatu instansi pemerintah untuk melibatkan instansiinstansi pemerintah lainnya agar Perda yang dibuat dapat mengenai sasarannya dengan lebih baik. Integrasi telah menjadi fokus dalam pengelolaan wilayah pesisir selama tiga dekade (Cicin-Sain 1998), dan banyak pengalaman yang dapat diperoleh dari upaya tersebut untuk pengelolaan hutan.

Komunikasi merupakan kunci utama dalam melakukan koordinasi dan integrasi. Bahkan di kantor kabupaten yang kecil pun, komunikasi diantara bagian sangat penting. Kelemahannya adalah bahwa komunikasi yang terjadi pada dasarnya sering bersifat linier, dalam artian bagian yang berbeda akan mengkaji dan menandatangani dokumen yang sama, tetapi tidak ada kerja sama atau diskusi antar bagian.

Koordinasi akan melibatkan instansi-instansi lainnya untuk turut bekerja sama, dan memberikan peluang kepada instansi-instansi tersebut untuk berpartisipasi dalam proses pengambilan keputusan. Proses integrasi kemudian akan mengkoordinasikan berbagai kepentingan yang berbeda dan menggabungkannya secara harmonis. Dengan demikian, konflik dapat dikurangi, pengulangan lebih sedikit, dan pada akhirnya tidak perlu membuat banyak Perda. Banyak instansi yang menolak upaya koordinasi dan integrasi karena mereka menganggap upaya-upaya seperti ini akan mengurangi kewenangan mereka. Kenyataannya, integrasi tidak mengurangi wewenang sebuah instansi. Sebaliknya, upaya-upaya ini mengurangi otonomi mereka. Integrasi yang efektif akan menghasilkan proses pembuatan peraturan yang lebih didukung oleh informasi yang lebih baik dan sistem tata kelola yang lebih efisien.

Alternatif A: Mengikuti cara-cara yang sama untuk pemberitahuan kepada masyarakat. Instansi-instansi pemerintah lainnya tidak akan diberi peran khusus dalam pengambilan keputusan, tetapi akan berpartisipasi seperti layaknya partisipasi masyarakat lainnya. Dalam hal ini, tidak ada koordinasi khusus yang dibutuhkan. Karena itu, kemajuan dalam hal koordinasi tidak akan banyak dicapai, dan keputusan-keputusan suatu instansi akan terus 
dilakukan tanpa melibatkan instansi-instansi lainnya, yang mungkin dapat memberikan masukan, informasi, dan saran yang lebih baik.

Alternatif B: Melaksanakan koordinasi oleh sebuah instansi. Instansi tersebut akan memberitahukan kepada instansi-instansi lain secara langsung dan meminta masukan dari mereka secara langsung juga. Meskipun kelihatannya efisien dan hemat biaya, namun ini bisa menjadi beban yang berat bagi instansi tersebut, khususnya jika anggaran dan staf nya memang sudah terbatas. Selain itu, instansiinstansi lainnya mungkin tidak bersedia membantu instansi sejenis tanpa mandat yang jelas. Untuk alternatif ini, koordinasi mungkin hanya berhasil sebagian saja.

Alternatif C: Melaksanakan koordinasi oleh Instansi koordinasi yang sudah ada atau oleh suatu badan koordinasi lain. Masing-masing tingkat pemerintahan telah memiliki beberapa kantor atau instansi yang bertanggung jawab untuk melakukan koordinasi berbagai kebijakan yang berbeda. Misalnya, di tingkat nasional, Badan Perencanaan dan Pembangunan Nasional (BAPPENAS), Sekretariat Koordinator Hubungan Ekonomi dan Sosial, dan Sekretariat Kabinet, yang semuanya memiliki tanggung jawab untuk mengkoordinasikan berbagai kebijakan. Di tingkat daerah, ada BAPPEDA dan Badan Pengelolaan Dampak Lingkungan Daerah (BAPEDALDA) untuk menangani berbagai isu lingkungan. Alternatif ini memiliki kelebihan, yaitu bisa mengandalkan infrastruktur yang ada, yang akan menghemat biaya. Namun, instansi-instansi yang sudah ada ini sering memiliki berbagai bias dan posisi tertentu dalam berbagai subyek, yang mungkin menjadi kendala kelangsungan reformasi yang sebenarnya. Selain itu, instansi yang ada mungkin harus diubah hingga tingkat tertentu untuk menangani koordinasi kebijakan sektor kehutanan.

Alternatif D: Membentuk badan koordinasi baru atau lembaga antar-instansi baru yang mengemban tanggung jawab koordinasi. Sebuah badan koordinasi baru dapat dibentuk untuk mengawasi koordinasi. Badan yang baru ini memiliki kelebihan, yaitu tidak akan mengandalkan tatanan politik yang ada, dan dapat disesuaikan dengan kebutuhan koordinasi kebijakan kehutanan. Kerugiannya, secara politis akan menghadapi kesulitan, dan memerlukan biaya yang besar untuk membentuk sebuah instansi baru. Biaya yang diperlukan bisa ditekan, jika instansi yang ada seperti Dinas Kehutanan dapat menyediakan staf yang handal dan biaya operasional yang memadai. Untuk membentuk instansi baru, banyak pertanyaan yang perlu dijawab seperti: apakah instansi tersebut menjadi penasihat atau memiliki wewenang untuk mengambil keputusan; apakah keanggotaannya hanya meliputi anggota-anggota pemerintah, atau anggota-anggota non-pemerintah juga; bagaimana penentuan keanggotaannya; apa yang harus menjadi lingkup tanggung jawabnya; seberapa sering instansi tersebut harus mengadakan pertemuan; dan apa yang harus menjadi aturan tata caranya.

\section{Tanggung gugat (Akuntabilitas)}

Tanggung gugat mungkin merupakan prinsip yang paling sering dikemukakan sebagai ciri tata kelola yang baik. Seorang pakar menjelaskannya sebagai 'landasan suatu tata kelola yang baik'. (Bennett, 2001). Ada banyak tipe tanggung gugat, dan para pakar menggolongkan tipe-tipe ini secara berbeda pula. Seorang pakar hukum mengatakan bahwa "tanggung gugat merupakan konsep yang rumit, dengan berbagai definisi yang berbeda dalam konteks yang berlainan sesuai dengan teori politik yang berbeda, sehingga tidak banyak artinya untuk mencapainya jika dipisahkan dari kondisi spesifik yang faktual . Tanggung gugat oleh karena itu bisa berarti demokrasi, legitimasi, kontrol, tanggapan, dan berbagai ciri lain dari suatu bentuk pemerintahan atau struktur tata kelola yang ideal" (Slaughter, 2001).

Misalnya, salah satu aliran akademis menggolongkan tanggung gugat menjadi tiga bentuk. Yang pertama, tanggung gugat politik, di mana kantor pemerintah atau seseorang bertanggung gugat terhadap seorang pejabat yang dipilih, sebuah badan legislatif, masyarakat yang memilih, atau manifestasi masyarakat madani serupa lainnya yang dijalankan oleh pemerintah. Yang kedua, tanggung gugat organisasi, dimana kantor pemerintah atau individu bertanggung gugat terhadap hierarki dalam organisasi tersebut, atau terhadap instansi lainnya dalam birokrasi tersebut; dan yang ketiga, tanggung gugat legal, dimana kantor pemerintah atau individu bertanggung gugat terhadap serangkaian UndangUndang atau berbagai peraturan yang mengatur berbagai tindakan mereka (ELI, 2003).

Aliran lainnya merujuk pada dua tipe tanggung gugat, yaitu tanggung gugat horisontal, di mana tanggung jawab didelegasikan kepada berbagai instansi yang terpisah; dan tanggung gugat vertikal (atau tanggung gugat sosial), di mana wakil-wakil masyarakat madani memiliki keterlibatan langsung (Reuben, 2003). Tanggung gugat terdapat pada dua tingkat, yaitu kepada instansi dan kepada diri sendiri. Disatu pihak, para pejabat pemerintah membuat berbagai keputusan atas nama instansi mereka dan instansi ini bertanggung gugat kepada instansi diatasnya. Di pihak lain, para pejabat tersebut juga 
melakukan kewajibannya untuk menjunjung tinggi tanggung jawab mereka dan untuk mematuhi UndangUndang. Sebagai individu, mereka juga bertanggung gugat (Turner dan Hulme, 1997), dan mungkin harus menghadapi berbagai kemungkinan sanksi atau hukuman dari lembaga peradilan apabila mereka menyalahgunakan wewenang dan tanggung jawabnya.

Fokus pembahasan berikut adalah tanggung gugat kelembagaan atau administratif, yaitu bagaimana suatu Perda mengatur cara Pemda melakukan pekerjaan mereka atau melangsungkan fungsi pengaturan masyarakat, untuk memastikan bahwa yang mereka lakukan itu konsisten dengan UndangUndang (Pope, 2000). (Namun harus diingat bahwa rendahnya tingkat tanggung gugat kepada diri sendiri mungkin merupakan masalah yang lebih besar di Indonesia). Tanggung gugat administratif di tingkat daerah sangat penting untuk memberantas korupsi yang merajalela secara keseluruhan. Namun, yang terpenting adalah bagaimana mengatasi masalah pengambilan keputusan yang sering menghadapi kendala keterbatasan pengetahuan hukum dan fakta, yang kelihatannya tidak begitu penting, namun sebenarnya juga sama pentingnya.

Proses pengambilan keputusan di tingkat Pemda terlalu sering dilakukan secara lisan. Misalnya, pernyataan seorang pejabat pemerintah yang tidak didukung oleh surat keputusan resmi-UndangUndang, peraturan atau keputusan- bisa bersifat menentukan. Selain itu, karena banyaknya Perda yang sering melibatkan bukan saja Pemda kabupaten, tetapi juga instansi yang mewakili Pemda provinsi dan Pemerintah Pusat, maka secara umum tidak ada satupun instansi yang mau bertanggung jawab untuk mengambil keputusan secara keseluruhan. Misalnya, izin-izin IPPK yang ditandatangani oleh Bupati Malinau, didasarkan pada perkiraan ukuran dan jenis pohon yang dibuat oleh Dinas Kehutanan Kabupaten Malinau, dan kantor Bupati menolak bertanggung jawab atas berbagai kesalahan yang mungkin terjadi (Gurodaboro kom.pri 2001).

Tanggung gugat administratif memerlukan empat komponen, yaitu (1) keputusan yang dibuat; (2) instansi tunggal yang berwenang-kepala instansi atau kepala pemerintahan-yang bertanggung jawab terhadap keputusan tersebut; (3) terdapat peluang untuk mengkaji keputusan tersebut, mempertimbangkan kembali, naik banding; dan (4) didasarkan pada penelaahan atau pertimbangan kembali, harus ada kemampuan untuk mengubah atau mencabut kembali keputusan tersebut. Keempat komponen ini didasarkan pada berbagai pokok peraturan administratif hukum (Aman dan Mayton, 2001). Berbagai tindakan yang diambil harus didukung oleh keputusan resmi yang menyatakan wewenang pihak yang mengambil keputusan tersebut; keputusan-keputusan ini harus diambil pada waktu yang tepat; dan sebaiknya bersifat konsisten atau tidak berubah-ubah.

Pembahasan tentang bagaimana tanggung gugat bisa diwujudkan terdapat dalam banyak referensi. Berbagai alternatif berikut difokuskan pada proses untuk melakukan pengkajian dan perbaikan terhadap keputusan-keputusan pemerintah. Alternatifalternatif di bawah ini berusaha untuk memasukkan banyak aspek tanggung gugat yang telah dibahas sebelumnya, termasuk aspek-aspek horisontal, vertikal, politik, organisasi dan legal. Yang pertama berkaitan dengan standar pengkajian. Di sini terdapat banyak standar yang digunakan untuk melakukan pengkajian terhadap suatu Perda. Misalnya apakah Perda itu tidak bertentangan dengan Undang-Undang yang berlaku, apakah sifatnya sewenang-wenang, mendadak atau dibuat tergesa-gesa, apakah telah didukung oleh fakta yang lebih dari cukup, dll. Untuk tahap pertama dalam penyusunan Perda, harus terdapat dua standar yang sangat sederhana, yaitu standar legalitas-yang membuktikan bahwa Perda tersebut telah sesuai dengan semua Undang-Undang yang berlaku; dan standar faktual-yang menunjukkan bahwa pembuatan suatu Perda telah didukung oleh semua fakta yang layak dipertimbangkan (tidak menjadi soal apakah instansi yang menyusun Perda itu mengetahui fakta-fakta tersebut atau tidak pada saat Perda itu disusun).

Alternatif A: Kajian administratif: Kajian ini melibatkan kemampuan sebuah lembaga administratif untuk mengkaji sebuah Perda, misalnya, melalui sebuah lembaga eksekutif pemerintahan seperti kantor Bupati. Idealnya, proses ini paling sedikit dilaksanakan dalam dua tahap, yaitu pengkajian oleh instansi atau departemen yang menyusun Perda itu sendiri; dan pengkajian oleh tim independen yang memiliki kewenangan lebih tinggi, namun tidak ada hubungannya dengan institusi pembuat Perda. Instansi ini bisa saja berupa sebuah tim yang bertanggung jawab langsung kepada Bupati atau bahkan mungkin sebuah institusi pemerintah yang ditunjuk di tingkat propinsi. Hanya dengan kewenangan independen yang lebih tinggi akan dihasilkan kajian yang obyektif, dan hasil keputusan evaluasinya tidak memihak. Keuntungan alternatif ini, jika dibandingkan dengan pengkajian yudisial, adalah bisa lebih fleksibel dan lebih cepat. Dan yang lebih penting lagi, kajian ini bisa dilaksanakan oleh instansi pemerintah yang lebih dikenal oleh masyarakat.

Alternatif B: Pengkajian yudisial: Pengkajian yudisial merupakan cara yang cukup umum untuk melakukan pengkajian Perda, tetapi jarang digunakan dan sering diwarnai oleh korupsi. Agar pengkajian yudisial bisa menjadi alternatif yang 
dapat dijalankan, Pemda harus berusaha membuka akses yang setara bagi masyarakat, artinya dengan melakukan penyuluhan yang intensif, perwakilan yang bebas, dan berbagai proses yang disederhanakan untuk melaksanakan peradilan. Beberapa kelompok LSM dan proyekproyek bantuan luar negeri telah mulai berupaya melakukan reformasi di bidang peradilan, tetapi indikasi awal menunjukkan bahwa tingkat pemahaman tentang pelaksanaan pengadilan masih sangat rendah (Ipo Kre kom.pri 2001).

Alternatif C: Kajian Legislatif: Badan legislatif di tingkat kabupaten (DPRD) bisa menciptakan mekanisme pengkajian Perda berdasarkan Undang-Undang. Hal ini dapat dilakukan melalui dengar pendapat dan hak untuk meneliti kebenaran yang dimilikinya. Menurut Pasal 18 dan 19 Undang-Undang 22/1999, DPRD memiliki wewenang dalam menyelesaikan masalahmasalah administratif dan melakukan pengawasan. Karena itu DPRD dapat berperan lebih banyak untuk menjamin pelaksanaan tanggung gugat dibandingkan peran yang sama mereka lakukan di masa lalu.

Alternatif D: Pembentukan sebuah dewan atau instansi independen. Sebuah Perda dapat disusun dan digunakan untuk membentuk suatu badan otonom yang independen yang bertanggung jawab untuk mengawasi, mengkaji dan menertibkan instansi-instansi pemerintah dan para pegawai negeri sipil. Meskipun dewan otonom ini masih merupakan bagian dari Pemda, namun karena sifatnya yang independen akan memberikan kesempatan kepadanya untuk menjadi lebih kritis terhadap instansi-instansi Pemda yang lain dan bahkan terhadap Bupatinya sendiri. Kunci keberhasilan badan otonom ini terletak pada masa jabatan anggotanya yang terbatas, dan mereka tidak boleh dikeluarkan karena permintaan suatu instansi tertentu.

Alternatif E: Pembentukan kelompok pengawas dari masyarakat atau lembaga pedesaan lainnya. Melalui suatu Perda, sebuah lembaga nonpemerintah dapat dibentuk untuk memantau dan mengawasi pelaksanaan Perda oleh instansiinstansi dalam lingkup Pemda. Lembaga nonpemerintah ini bisa berbentuk lembaga-lembaga swadaya masyarakat (LSM) atau atau bisa juga kelompok semacam KADIN untuk tingkat desa. Bisa juga lembaga-lembaga kemasyarakatan di desa, dengan wewenang untuk mengajukan petisi dan mencari keadilan atas berbagai ketidakpuasan masyarakat (Bennett, 2001). Kelompok-kelompok seperti ini sebenarnya sudah ada, misalnya Gabungan Pengamat Polisi-Gamatpol) yang berupaya menegakkan peraturan-peraturan di tingkat nasional. Kelompok semacam ini juga bisa dibentuk di tingkat daerah. Idealnya, menurut Undang-Undang, pemerintah melalui instansiinstansinya harus memberikan tanggapan terhadap berbagai komentar dan tuntutan yang disampaikan oleh kelompok-kelompok pengawas seperti ini.

\section{E. Kejelasan}

Kejelasan merupakan prasyarat agar Perda dipatuhi semua orang. Jika masyarakat harus mematuhi sebuah peraturan, selain peraturan itu harus diterima oleh masyarakat, maka peraturan tersebut harus jelas dan bisa dipahami (Seidman, 2001; Botchway, 2001). Bagaimanapun patuhnya masyarakat, apabila peraturannya sendiri kurang jelas, maka tidak akan bisa dipatuhi. Adanya kejelasan membuat masyarakat mengetahui isinya dan memahami kewajiban yang harus dipenuhinya.

Kejelasan dapat dilihat dari bagaimana cara Perda itu disusun dan dipublikasikan. Dokumen legal sering ditulis dengan kata-kata dan istilah yang kurang dapat dipahami oleh masyarakat umum dan sering bermakna ganda. Kadang-kadang hal ini disengaja, tetapi yang lebih sering terjadi, penyebabnya adalah cara penulisan yang sulit dimengerti orang awam. Meskipun mungkin tidak ada alternatif lain yang dapat menggantikan ketrampilan menulis Perda dengan baik, tetapi ada beberapa cara yang dapat menjelaskan peraturan melalui penjelasan tambahan.

Alternatif A: Aturan Penjelasan. Cara seperti ini sudah banyak sekali dilakukan dalam rancangan peraturan di Indonesia. Hampir setiap naskah Undang-Undang dan peraturan di tingkat nasional dan daerah selalu dilengkapi dengan aturan penjelasannya, yang menguraikan riwayat dan arti pasal-pasal tertentu dari Undang-Undang dan peraturan yang dimaksud. Perda juga akan sangat baik jika menyertakan penjelasannya secara teratur. Selain itu, berbagai penjelasan perlu ditulis dengan lebih gamblang. Seringkali, aturan penjelasan ini ditulis secara tergesa-gesa setelah sebagian besar dari naskah Perda selesai dirancang dan siap untuk disahkan. Waktu atau perhatian yang diberikan untuk menguraikan berbagai penjelasan terhadap ketetapan yang bermakna ganda hanya sedikit sekali. Seharusnya, penjelasan itu ditulis secara bersamaan dengan rancangan peraturan yang dibuat.

Alternatif B: Penjelasan kepada masyarakat dan penerbitan buletin. Kepala pemerintahan, seperti Bupati atau Gubernur, dapat mengeluarkan sebuah keterangan lengkap yang menyertai sebuah Perda, untuk memberikan ikhtisar Perda dan persyaratannya secara lebih sederhana dan 
lebih komprehensif dibandingkan aturan penjelasannya. Buletin-buletin tentang kemajuan yang dicapai selama penerapan Perda juga bisa tetap diterbitkan dan disebarkan secara berkala.

Alternatif C: Pertemuan-pertemuan publik. Pertemuan-pertemuan publik yang dilakukan saat ini sebenarnya menjalankan fungsi 'sosialisasi'. Pertemuan semacam ini pada dasarnya merupakan bentuk penjelasan tentang isi suatu Perda dan tujuan apa yang akan dicapainya. Pertemuan publik biasanya berlangsung sebelum pengesahan sebuah Perda, sebagai pengganti proses konsultasi. Sosialisasi terjadi setelah suatu peraturan disahkan, sebagai bentuk komunikasi tambahan. Pertemuan-pertemuan tersebut bisa berlangsung di berbagai tempat yang berbeda sehingga bisa sampai kepada masyarakat yang akan paling terkena peraturan, khususnya jika anggaran yang tersedia bagi pemerintah merupakan kendala.

Alternatif D: Rekaman-rekaman radio/DVD. Selain penggunaan siaran-siaran radio seperti yang dibahas sebelumnya, penjelasan Perda juga bisa dibuat dalam digital video disks (DVD). Komunitas masyarakat yang tinggal di daerah-daerah terpencil dan tidak terjangkau siaran televisi dan radio, sering bergantung pada peralatan DVD untuk memperoleh hiburan. Pembuatan dan sirkulasi DVD yang membahas berbagai isu kebijakan publik bisa menjadi cara-cara yang sangat murah dan efisien untuk menyampaikan Perda kepada masyarakat.

\section{F. Validitas ilmiah dan berbagai pertimbangan sosial ekonomi}

Perda apa pun yang berkaitan dengan pengelolaan sumber daya alam harus dibuat berdasarkan hasil temuan ilmiah apabila diharapkan dapat membantu pengelolaan sumber daya alam secara efektif dan lestari. Para ilmuwan akan sependapat dengan penggunaan dasar-dasar ilmiah yang sesuaipengelolaan yang berbasiskan ekosistem, pengelolaan adaptif, pemantauan dan evaluasi, dll. -tetapi Pemda dan para pengelola lapangan sering tidak mengetahui hal-hal tersebut atau cara melaksanakannya. Selain itu, secara universal juga disepakati bahwa jika upaya untuk melakukan konservasi sumber daya alam ingin berhasil, maka aspek-aspek ekonomi dan sosial yang ada di seputar sumber daya tersebut dan masyarakat yang memanfaatkannya juga perlu diperhitungkan (Borrini-Feyerabend, 1997).

Pertanyaan kuncinya adalah bagaimana Pemda bisa bekerja sama dengan para ilmuwan dan akademisi sehingga validitas ilmiah dan pengkajian sosial-ekonomi dalam Perda dapat ditingkatkan? Jawabannya, harus ada persyaratan bahwa Perda tersebut perlu dikaji secara ilmiah, termasuk aspek sosial-ekonominya. Hal ini dapat dilakukan melalui proses tertentu atau bisa merupakan bagian dari proses partisipasi masyarakat. Cara apa pun yang akan ditempuh, diperlukan adanya peluang untuk melakukan kajian ilmiah dan masukan dari para pakar akademisi.

Alternatif A: Tenaga ilmiah yang profesional. Jika Pemda memiliki tenaga yang cukup berpengalaman, maka kajian ilmiah terhadap Perda baru dan berbagai kegiatan dapat dilakukan secara internal. Sebaiknya ada dokumen publik yang dipublikasikan untuk menunjukkan bahwa kajian tersebut telah dilaksanakan.

Alternatif B: Tim masyarakat. Jika Pemda tidak memiliki personil yang memadai, atau meskipun memilikinya, namun menginginkan bantuan eksternal, maka sebuah tim beranggotakan warga masyarakat secara formal dapat dibentuk. Tugas tim adalah melakukan kajian dan membuat rekomendasi untuk Pemda kabupaten.

Alternatif C: Panduan pemerintah. Jika instansi pemerintah provinsi atau pemerintah pusat memiliki pengalaman yang lebih luas, mereka dapat mempersiapkan dan menerbitkan buku panduan untuk membantu Pemda membuat berbagai Perda yang baik secara ilmiah. Namun kegunaan dokumen seperti ini terbatas. Bukubuku panduan sering bersifat umum, tanpa rincian yang memadai tentang bagaimana menyusun Perda. Tanpa panduan yang rinci dan instruksi langsung, para pejabat Pemda mungkin tidak dapat menggunakan buku-buku panduan tersebut secara efektif.

Alternatif D: Pengkajian secara ad-hoc. Pengkajian secara ad-hoc akan mengharuskan Pemda untuk membentuk tim ad-hoc yang akan bekerja dalam waktu pendek untuk membahas Perda tertentu. Dengan cara seperti ini, Pemda akan memperoleh masukan dari para pakar tanpa harus mengeluarkan biaya untuk menggaji pegawai tetap. Instansi-instansi pemerintah propinsi atau pemerintah pusat dapat menugaskan tim seperti ini secara bergiliran di beberapa kabupaten, atau suatu tim ad-hoc dapat bergabung dalam LSM atau wadah lainnya berdasarkan kasus per kasus.

Alternatif E: Pengkajian jarak jauh. Dialog dan pengkajian oleh para ilmuwan dapat dilakukan dari jarak jauh dengan menggunakan radio, faksimili, telepon, dan internet. Meskipun penggunaan alat elektronik ini mungkin menimbulkan resiko logistik, namun komunikasi jarak jauh tidak memerlukan biaya tinggi, dan 
merupakan cara yang efisien untuk melakukan analisa ilmiah apabila Pemda setempat tidak memiliki ilmuwan yang memadai. Sebelum dilakukan pengkajian, sebuah tim Pemda mungkin dapat ditugaskan untuk mengumpulkan data yang diperlukan guna dianalisis dalam persiapan pengkajian jarak jauh.

\section{G. Keberlanjutan sistem anggaran}

Sistem anggaran yang berkelanjutan merupakan jaminan tersedianya dana yang memadai untuk mengimplementasikan Perda. Namun kebanyakan Pemda mengalokasikan sebagian besar dananya untuk berbagai kegiatan operasional dan administrasi-gaji, dana pensiun, biaya-biaya pengeluaran kantor, dll. Hanya sedikit sekali anggaran yang dialokasikan untuk biaya-biaya yang sifatnya penyusunan program dan rencana pembangunan, kecuali jika tersedia sumber pendapatan khusus. Keterbatasan kemampuan finansial seperti inilah yang menjadi salah satu alasan utama lemahnya penegakan hukum di Indonesia (ADB, 2002b).

Undang-Undang 25/1999 telah mengatur perimbangan alokasi dana anggaran yang berkaitan dengan sumber daya hutan secara langsung untuk Pemda. Oleh karena itu, dana untuk melakukan beberapa pilihan alternatif kegiatan baru telah tersedia.

Alternatif A: Penentuan Dana Reboisasi regional. Seperti halnya pemerintah pusat yang memungut Dana Reboisasi, Pemda Provinsi atau Kabupaten juga dapat menentukan Dana Reboisasinya sendiri untuk program konservasi hutan. Masing-masing Pemda dapat menentukan persentase tertentu dari penghasilan yang diperoleh dari kegiatan kehutanan untuk diinvestasikan kembali dalam kegiatan pengelolaan dan konservasi sumber daya alam. Keuntungan dari cara ini adalah adanya jaminan sumber dana dari kelompok yang menggunakan sumber daya hutan untuk tujuan konservasi, sesuai prinsip siapa yang memakai, merekalah yang harus membayar.

Alternatif B: Dana khusus dialokasikan dari anggaran umum. Jika karena satu dan lain hal Pemda tidak mau mendanai program konservasi dengan biaya hasil pungutan kegiatan penebangan, maka dana program konservasi diambil dari anggaran umum. Pada hakekatnya ini akan menunjukkan bahwa seluruh masyarakat sama-sama menanggung biaya pengelolaan hutan, bukan hanya para pengguna hasil hutan saja.

Alternatif C: Penggunaan sistem anggaran tahunan. Alternatif ini tidak akan berusaha mencari jaminan dana konservasi dari sumber mana pun. Sebaliknya, alternatif ini hanya bergantung pada kebutuhan dana tahunan untuk mendanai konservasi hutan dalam setiap tahun anggaran. Pendekatan ini tidak menjamin tersedianya dana yang berkelanjutan dari tahun ke tahun.

\section{H. Kepastian hukum}

Kepastian hukum pada hakekatnya merupakan inti masalah dalam tata kelola yang baik dan supremasi hukum. Kepastian hukum dibutuhkan sebagai bagian terpenting dari proses maupun substansi Perda. Misalnya, masyarakat perlu mengetahui bagaimana Perda disusun-Perda-perda apa saja yang sudah berlaku dan kapan, Perda mana yang menggantikan Perda lainnya, dll. Masyarakat juga perlu mengetahui bagaimana Perda-perda tersebut dilaksanakan-apa arti dan tujuannya, kriteria mana yang mengatur tindakan tertentu, dll. Kepastian hukum pada dasarnya sangat penting untuk mencapai sistem pemerintahan yang efisien dan berkeadilan.

Perencanaan ekonomi dan investasi membutuhkan kepastian. Misalnya, Gubernur Kalimantan Timur menyusun Perda No. 20/2000, yang mewajibkan HPH untuk membayar ganti rugi sebesar Rp 1.500,00 per meter kubik kayu kepada masyarakat pemilik lahan yang kayunya ditebang. Upaya untuk mengumpulkan pungutan dari HPH yang sudah tidak beroperasi lagi menimbulkan banyak sekali kebingungan. Peraturan pembayaran ganti rugi tidak menciptakan kepastian hukum. Konservasi lingkungan juga memerlukan kepastian hukum. Misalnya, para pengusaha HPH yang sebelumnya mematuhi peraturan-peraturan pemerintah pusat tentang tebang pilih, tidak lagi memiliki insentif untuk melakukan hal ini ketika Pemda mengeluarkan IPPK yang mengizinkan kegiatan tebang habis di lahan-lahan konsesi mereka. Masyarakat yang tidak memiliki kepastian atas kepemilikan lahan mereka juga tidak akan mau melakukan konservasi di lahan tersebut dalam jangka panjang (Lynch, 2001; Smith dan Martin, 2000).

Keadilan sosial juga memerlukan adanya kepastian hukum. Misalnya, masyarakat yang sumber dayanya terbatas tidak memiliki sarana untuk ikut mempengaruhi dan mengikuti perubahan sistem hukum. Adanya kepentingan tertentu dan politik uang seringkali mendorong perubahan-perubahan legislatif dengan cepat dan tanpa memberikan peringatan kepada tujuan-tujuan mereka sendiri. Suatu sistem hukum yang didasarkan pada kepastian tidak akan mudah terpengaruh oleh dorongan perubahan seperti ini.

Kepastian hukum harus seimbang dengan fleksibilitas-peningkatan suatu kualitas tertentu akan mengorbankan kualitas lainnya. Apakah Pemda akan memprioritaskan kepastian hukum dibandingkan fleksibilitas atau sebaliknya, perlu didasarkan pada kondisi-kondisi tertentu dan masalah yang sedang dihadapi. Beberapa alternatif dapat dipilih dengan 
memperhatikan proses penyusunan Perdanya dan pelaksanaan Perda itu sendiri (substansi):

\section{Kepastian dalam proses penyusunan Perda} Alternatif A: Mencantumkan masa berlakunya Perda. Alternatif ini mengharuskan sebuah Perda diberlakukan dalam batas waktu tertentu, atau jelas masa berlakunya. Dengan melakukan hal ini akan menjadi jelas kapan sebuah Perda perlu diganti dan ditentukan jadwalnya untuk melakukan penggantian ini. Karena itu, semua pihak yang berkepentingan akan mengetahui kapan sebuah Perda dipertimbangkan kembali untuk direvisi, sehingga mereka dapat membuat rencana. Keuntungan dibuatnya batas waktu ini adalah untuk memacu dilakukannya perbaikan untuk meningkatkan kualitas Perda dari waktu ke waktu; namun kerugiannya adalah menghabiskan waktu dan tenaga, karena proses legislatif perlu diulangi secara berkala.

Alternatif B: Mencantumkan waktu pengkajian dalam Perda. Alasan untuk menentukan waktu pengkajian mirip dengan penetapan batas waktu di atas. Tetapi alternatif ini sebenarnya dimaksudkan untuk tidak membiarkan sebuah Perda habis masa berlakunya tanpa ada pengkajian; alternatif ini menghendaki diberikannya kesempatan untuk mengkaji sebuah Perda dan membuat rekomendasi perubahan. Kerugiannya adalah tidak ada persyaratan bahwa Perda tersebut benar-benar akan diubah meskipun hasil kajian merekomendasikannya.

Alternatif C: Memberlakukan sebuah Perda yang memayungi proses penyusunan Perda lainnya. Dengan membuat sebuah Perda yang memayungi Perda lainnya, maka akan tercipta proses yang seragam untuk mengevaluasi, meninjau ulang, dan mengubah Perda-perda lainnya. Dengan alternatif ini, kriteria dapat disusun untuk menentukan kapan sebuah Perda bisa dikaji, dan bagaimana amandemennya dapat dibuat. Selain itu, juga dapat diciptakan mekanisme koordinasi dalam membuat keputusan, baik di bidang legislatif maupun administratif pemerintahan.

Alternatif D: Mengurangi penggunaan istilah 'pencabutan tidak langsung'. Suatu Perda baru tentu mempunyai hubungan dengan Perda sebelumnya-mungkin Perda baru ini menggantikannya, memodifikasi, atau mengamandemen Perda lama. Konvensi standar peraturan perundangan yang dibuat di Indonesia biasanya menyebutkan bahwa semua peraturan yang ada tetap berlaku, kecuali jika bertentangan dengan peraturan baru tersebut. Kalimat seperti ini merupakan "pencabutan tidak langsung" dan menyebabkan pemahaman terhadap Perda menjadi sangat sulit, karena tidak ada panduan yang menjelaskan mana yang bertentangan dan mana yang tidak. Pemda harus lebih berupaya untuk memastikan bahwa kalimat seperti ini hanya digunakan apabila terpaksa, dalam kondisikondisi yang sangat khusus dan terbatas.

\section{Kepastian dalam implementasi Perda}

Alternatif A: Membuat persyaratan-persyaratan untuk melaksanakan kegiatan secara langsung yang disebut dalam Perda. Kebanyakan peraturan yang berlaku di semua tingkat pemerintahan di Indonesia hanya menyampaikan panduan kriteria yang sangat umum, dan kemudian menyerahkan pelaksanaannya kepada lembaga eksekutif. Akibatnya, pelaksanaan peraturan menjadi tidak konsisten pada saat para pimpinan lembaga eksekutif diganti atau pada saat kebutuhan politik mereka berubah. Daripada menyerahkan aturan pelaksanaan yang rinci kepada lembaga eksekutif, peraturan itu sendiri harus bisa menjelaskannya.

Alternatif B: Membuat penjelasan yang lengkap untuk keputusan administratif. Meskipun lembaga eksekutif membuat sebagian besar persyaratan melalui keputusan-keputusannya, masih memungkinkan di dalam Perda untuk menjelaskan bagaimana keputusan-keputusan tersebut sebaiknya dibuat.

Alternatif C: Menetapkan mata rantai wewenang untuk keputusan-keputusan administratif. Kepastian hukum sering mengalami masa-masa sulit hanya karena tidak ada yang tahu siapa yang bertanggung jawab untuk melaksanakan keputusan-keputusan setelah sebuah Perda disusun. Setiap Perda perlu mencantumkan peranan DPRD, Bupati, dan Camat. Dalam hal Perda tersebut melibatkan masyarakat adat, maka para pemuka adat dan kelompok-kelompok adat juga perlu ditentukan peranannya.

\section{Fleksibilitas administratif}

Fleksibilitas sering terjadi pada saat diperlukannya suatu pertimbangan khusus untuk mengatur sesuatu. Pertimbangan khusus ini bisa digunakan oleh instansi pemerintah baik secara positif maupun negatif. Dalam hal-hal tertentu, pertimbangan khusus penting digunakan untuk sebuah Perda karena tidak ada satupun peraturan yang secara efektif dapat memperkirakan semua kejadian atau kenyataan yang perlu diselesaikan di lapangan (Botchway, 2001). Namun di lain pihak, pertimbangan khusus yang terlalu sering digunakan bisa menyebabkan kesewenang-wenangan, korupsi, dan sulit diprediksi. Tidak seperti kepastian hukum yang perlu diuraikan secara jelas dalam Perda, pertimbangan khusus bisa 
bersifat eksplisit atau implisit. Misalnya, jika sebuah Perda tidak secara langsung menyinggung masalah tertentu, maka artinya instansi pelaksana mempunyai pertimbangan khusus untuk melakukan suatu tindakan tertentu sesuai dengan caranya sendiri. Pertimbangan khusus bersifat sangat umum dan mempunyai kepastian hukum yang kuat, yang bisa dengan cepat membuat kesewenangan dalam pengambilan keputusan. Jika Perda memiliki beberapa standar atau kriteria, atau memungkinkan Bupati membuat keputusan akhir, maka pertimbangan khusus ini akan menjadi lebih terbatas.

Pertimbangan khusus yang terbatas bermanfaat untuk mencapai beberapa tujuan. Pertama, memungkinkan penerapan Perda yang lebih tepat, adil dan berlaku untuk semua kondisi individu. Penerapan Perda dengan cara yang sama untuk semua keadaan bisa berujung kepada ketidakadilan dan tidak efisien. Kedua, mengurangi berbagai kesenjangan dalam peraturan. Perda tidak bisa mengantisipasi setiap kejadian atau keadaan. Pertimbangan khusus dapat digunakan untuk menjalankan sebuah Perda dalam berbagai situasi berbeda dengan cara yang berbeda pula. Ketiga, meningkatkan efisiensi dalam sistem hukum. Daripada menyusun Perda-perda baru-yang membuang waktu dan proses yang tidak mudah-, pertimbangan khusus lebih baik digunakan untuk mengatasi situasi yang sangat beragam dengan peraturan yang sudah ada.
Alternatif A: Membolehkan untuk menguraikan secara rinci hal-hal yang dituangkan dalam Keputusan Bupati atau Keputusan Gubernur atau keputusan administratif lainnya. Hal seperti ini sudah sangat terbiasa dilakukan di Indonesia dan telah menjadi patokan dalam pembuatan peraturan selama bertahun-tahun. Umumnya, sebuah peraturan menyertakan penjelasan yang rinci untuk ditetapkan dalam suatu keputusan administratif. Namun, peraturan sering tidak menyatakannya lebih jauh dari itu. Malahan peraturan dapat menyertakan beberapa rincian dasar atau subyek yang harus ditanggulangi dalam keputusan administratif. Selain itu, peraturan tersebut juga dapat menyertakan berbagai proses yang harus ditempuh oleh Pemda dalam menyusun Perda untuk memastikan bahwa prinsip-prinsip tata kelola yang baik tidak hanya diterapkan di bidang legislatif, tetapi juga di bidang administratif.

Alternatif B: Memasukkan standar-standar dan kriteria di dalam Perda untuk pembuatan keputusan administratif. Alternatif ini memungkinkan Bupati atau Gubernur untuk membuat keputusan yang berdasarkan parameter atau kriteria tertentu. Misalnya, izin-izin yang dikeluarkan oleh Bupati atau Gubernur harus sesuai dengan kriteria dan standar yang telah ditetapkan di dalam Perda tersebut, dan harus didukung oleh dokumentasi yang memadai. 


\section{Mekanisme Penyusunan Peraturan Daerah Tentang Kehutanan}

\section{A. Proses Umum}

Setelah Pemda memahami dengan baik prinsipprinsip dasar untuk membuat peraturan perundangan, selanjutnya mereka perlu mulai mengembangkan kerangka kerja dan mulai melakukan penyusunan Perda. Perumusan sebuah Perda dapat dipandang sebagai latihan untuk memecahkan masalah secara rasional (Seidman dkk., 2001). Seperti halnya dalam pemecahan masalah apa pun, langkah pertama yang perlu dilakukan adalah mengidentifikasi permasalahannya dahulu; kemudian mengidentifikasi dan menganalisa kemungkinan penyelesaiannya untuk mengatasi masalah tersebut. Jika setelah melihat berbagai pertimbangan akhirnya diputuskan untuk menyusun sebuah Perda baru, maka langkah-langkah berikut ini dapat dilakukan.

The Organisation for Economic Cooperation and Development (OECD) membuat 10 pertanyaan yang harus dijawab Pemda sebelum memutuskan untuk menyusun Perda baru, yaitu.

1. Apakah permasalahannya telah terdefinisikan dengan jelas?

2. Apakah tindakan pemerintah dapat dijadikan dasar pembenaran?

3. Apakah penyusunan Perda merupakan tindakan terbaik yang dapat dilakukan pemerintah?

4. Apakah tindakan tersebut ada dasar hukumnya?

5. Pada tingkat pemerintahan yang mana yang tindakan ini paling sesuai?

6. Apakah penyusunan Perda baru lebih besar manfaatnya dibandingkan biaya yang harus dikeluarkan untuk membuatnya?

7. Apakah Perda ini dampaknya secara transparan merata untuk seluruh pihak yang terkait?

8. Apakah Perda tersebut telah jelas, konsisten, dapat dipahami, dan bisa diakses oleh semua pihak terkait?

9. Apakah semua pihak yang berkepentingan mempunyai kesempatan memberikan pandanganpandangan mereka?

10. Bagaimana agar peraturan yang dibuat dapat dipatuhi dan tujuan penyusunan Perda dapat tercapai?

Semua pertanyaan tersebut, kecuali tiga yang terakhir, perlu dijawab terlebih dahulu sebelum merancang Perda - pertanyaan-pertanyaan ini harus dijawab dalam analisis lingkup dan kajian kebutuhan, dan dibahas dalam laporan penelitian. Rencana untuk menjawab tiga pertanyaan terakhir juga harus tertuang dalam laporan penelitian tersebut.

Pada umumnya, penyusunan Perda baru harus mencakup tujuh langkah sebagai berikut.

1. Pengkajian kebutuhan/identifikasi masalah. Pengkajian dimaksudkan sebagai upaya untuk merumuskan, menetapkan, dan menentukan prioritas masalah yang dihadapi dalam pengelolaan hutan, yang mempengaruhi semua pihak yang berkepentingan. Berbagai pihak yang berkepentingan dengan hutan akan menghadapi masalah yang berbeda. Para pemegang $\mathrm{HPH}$ akan lebih peduli terhadap berbagai aturan yang membebaninya dan biaya-biaya ekonomi yang terkait dengan kewajiban pengelolaan hutan; masyarakat lebih tertarik dengan hak-hak kepemilikan dan pemanfaatan lahan; LSM akan peduli dengan masalah-masalah konservasi dan kelestarian hutan. Tahap ini juga mencakup penentuan prioritas dan kelayakan, seperti penentuan bentuk dan lingkup peraturan apa yang paling mendesak, dan langkah apa yang paling efisien bisa dilakukan.

2. Identifikasi legalitas Perda. Analisis mengenai infrastruktur hukum dan kemampuan Pemda adalah langkah kedua dalam penyusunan Perda. Langkah ini meliputi inventarisasi peraturan hukum dan perundang-undangan yang ada dan evaluasi ketrampilan pegawai Pemda di bidang hukum. Kegiatan ini juga meliputi evaluasi pelaksanaan dan penegakan hukum yang ada saat ini. Seringkali, masalah yang dihadapi mungkin dapat diatasi dengan melakukan penegakan peraturan yang ada, dan tidak dengan menyusun Perda baru. Pemahaman terhadap landasan hukum yang ada sekarang merupakan langkah pertama untuk mengembangkan sebuah kerangka kerja hukum yang baru. Keinginan dan kebutuhan untuk menyusun Perda memerlukan suatu pengkajian.

3. Persiapan laporan penelitian. Laporan resmi yang menguraikan ringkasan hasil analisa kebutuhan dan 
pertimbangan-pertimbangan hukum perlu disiapkan sebagai landasan untuk merancang Perda baru. Laporan penelitian pada dasarnya mengupas alasanalasan untuk menyusun Perda baru, tujuan Perda, cakupan serta isi Perda, dan proses yang akan dilakukan untuk menyusun Perda tersebut. Laporan ini disusun oleh sebuah tim yang beranggotakan para pakar dari kalangan pemerintah dan non-pemerintah, dan dibantu oleh tim penasihat atau konsultan. Partisipasi dan keterlibatan aktif dari masyarakat dalam mempersiapkan laporan ini juga harus diusahakan; dengan kata lain, persiapan pembuatan laporan ini harus mematuhi prinsip-prinsip yang sama dengan persiapan penyusunan Perda itu sendiri.

4. Merancang Perda. Proses pembuatan rancangan Perda memerlukan beberapa langkah berikut. Pertama, sebuah tim kerja dibentuk untuk menyusun rancangan Perda. Tim ini tidak harus besar, tetapi jumlahnya bisa bervariasi dari satu Pemda dengan Pemda lainnya. Tim ini dipilih dari para pejabat Pemda dan kalangan akademisi, LSM dan tokoh-tokoh masyarakat. Kelompok-kelompok pihak yang berkepentingan, kelompok konsultan, atau kelompok penasihat, semuanya dapat memberikan komentar dan saran kepada tim kerja tersebut. Kelompokkelompok ini bekerja berdasarkan laporan penelitian untuk membuat pokok-pokok dan kerangka kerja dasar dari rancangan Perda tersebut. Kemudian, pokok-pokok isi rancangan Perda akan dijabarkan lebih lanjut melalui serangkaian diskusi perumusan rancangan yang dilakukan oleh tim kerja. Disini penting melibatkan pejabat legislatif dan administratif sejak awal proses ini. Kebiasaan selama ini adalah peraturan disusun melalui suatu proses legislatif atau proses eksekutif, tanpa banyak melibatkan instansi lain sampai tahap penyelesaian. Kebiasaan ini menyulitkan dan menghambat proses legislatif. Hubungan antara dua lembaga pemerintah ini sangat kuat: yang satu membuat peraturan dan yang lain melaksanakannya. Karena itu koordinasi berbagai kebijakan oleh kedua lembaga ini harus berlangsung sejak dari awal.

5. Kajian terhadap rancangan Perda oleh masyarakat. Proses konsultasi ini dilakukan agar terjadi aliran informasi dua arah: DPRD harus memberitahu masyarakat tentang peraturan yang diusulkannya dengan alasan-alasan, penilaian, dan konsekuensi aturan tersebut; dan pada saat yang sama, masyarakat harus memberikan komentar dan kepeduliannya kepada DPRD. Karena itu, kedua pihak ini memiliki tanggung jawab masing-masing. Kajian oleh masyarakat dapat berlangsung dalam beberapa tahap. Pertama, penyebaran informasi tentang rancangan Perda ke desa-desa dan masyarakat di kabupaten atau provinsi. Kemudian dilanjutkan oleh serangkaian pertemuan terbuka dengan masyarakat yang diadakan di berbagai desa. Selain itu, serangkaian pertemuan dengan pihak yang berkepentingan perlu diadakan secara terpisah. Pertemuan tersebut menyertakan para pejabat pemerintahan di tingkat provinsi dan pusat dan para pejabat Pemda kabupaten yang berdekatan, wakilwakil dari LSM baik dari kelompok-kelompok konservasi dan kelompok-kelompok industri, serta kalangan akademisi.

6. Perbaikan rancangan Perda. Berdasarkan hasil kajian oleh masyarakat, rancangan Perda kemudian direvisi. Sebagai bagian dari proses ini, tim kerja perlu menganalisa komentar-komentar yang diterima dan menyiapkan laporan terpisah yang meringkas komentar-komentar tersebut dan memberikan tanggapannya. Tanggapan ini harus menjelaskan bagaimana rancangan Perda ini akan diubah untuk mengakomodasikan berbagai komentar serta memberikan alasan-alasan untuk perubahan yang akan dilakukan. Selain itu, tanggapan ini juga harus menjelaskan alasan-alasan mengapa rancangan Perda tersebut tidak dirubah bila memang tidak perlu merubahnya.

\section{Pengesahan rancangan Perda. Rancangan Perda} kemudian dibahas dan dipertimbangkan pengesahannya oleh DPRD. Pengesahan merupakan langkah terakhir dalam penyusunan Perda baru, tetapi juga merupakan langkah awal dalam menerapkan Perda baru. Salah satu aspek terpenting agar Perda berhasil diterapkan adalah perlunya masa transisi sebelum Perda tersebut benar-benar diterapkan. Perda baru tidak harus berlaku segera setelah pengesahan; sebaliknya, harus ada tenggang waktu untuk awal masa berlakunya sehingga persiapan-persiapan yang memadai dapat dilakukan, termasuk kepedulian masyarakat atas persyaratanpersyaratan baru, dan pelatihan dan pendidikan untuk instansi pelaksana dan para petugas yang menjalankannya.

\section{B. Konsep Kerangka Kerja Peraturan Perundangan}

Untuk merancang peraturan perundangan yang berbeda untuk setiap keadaan, dapat dilakukan dua pendekatan umum. Yang pertama, Pemda dapat segera mulai menyusun Perda mengenai topik atau sektor-sektor tertentu, dengan rincian penyelesaian masalah untuk masing-masing sektor; dan yang kedua, penyusunan Perda dapat dimulai dengan membuat serangkaian aturan administratif umum, yang membentuk kerangka kerja kelembagaan untuk Perda sektoral berikutnya. Secara umum, makalah ini merekomendasikan pendekatan yang kedua.

Memang lebih masuk akal untuk menyiapkan sebuah Perda yang berisikan kerangka aturan-aturan dasar sebagai landasan, atau kerangka kerja untuk 
penyusunan Perda yang lainnya. Sebuah kerangka Perda akan menyebutkan tujuan-tujuan dasar, berbagai prinsip, proses, dan standar untuk suatu bidang yang akan ditatakelolakan -seperti kehutanan. Kerangka kerja ini akan meletakkan dasar-dasar mekanisme tata kelola, yaitu: menentukan agenda kegiatan; melakukan koordinasi; membentuk berbagai kelembagaan yang penting; memastikan penyediaan dana yang diperlukan; dan mungkin menangani beberapa elemen substansi dasar seperti pendidikan dan penyuluhan. Kerangka kerja dapat juga mengatur jalannya proses untuk memperoleh informasi dan penyebarluasannya, seperti Undang-Undang Kebebasan Pers, atau mungkin membuat mekanisme pengkajian administratif dan tanggung gugat seperti UndangUndang Prosedur Administratif (Andreen, 2000). Secara khusus, kerangka kerja untuk penyusunan Perda yang efektif akan mencapai beberapa sasaran: (1) menetapkan agenda pengelolaan sumber daya alam termasuk tujuan, visi, dan prioritas kegiatan konservasi dan pengelolaan sumber daya; (2) menggariskan peran dan tanggung jawab masingmasing institusi yang ikut serta dalam pengelolaan sumber daya alam (mungkin termasuk membuat atau merubah institusi-institusi pemerintah dan LSM); (3) membuat daftar kebutuhan informasi untuk berbagai inisiatif pengelolaan di masa mendatang; (4) menjamin ketersediaan sumber dana untuk pengelolaan sumber daya alam; dan (5) jika memungkinkan dan dapat dilaksanakan, membuat beberapa program dan kegiatan sebagai agenda pengelolaan.
Beberapa hal yang tidak kalah pentingnya, namun tidak termasuk dalam kerangka dasar Perda adalah: tidak berusaha mengelola berbagai kegiatan dengan pengalaman pengetahuan yang sangat terbataspengelolaan seperti ini dapat ditampung dalam Perda lain. Di sebuah kabupaten yang kemampuannya tidak memadai atau pengalamannya sedikit, mungkin sulit untuk menyusun Perda yang sangat rinci dan teknis. Meskipun kabupaten tersebut berhasil dalam menyusun Perda baru (seringkali melalui proyek bantuan luar negeri atau LSM internasional), Pemda yang bersangkutan mungkin tidak memiliki cukup kemampuan untuk melaksanakan atau menegakkan peraturan yang dibuatnya. Sebuah kerangka kerja Perda sebenarnya merupakan cara untuk mengembangkan kapasitas secara bertahap. Pengembangan suatu peraturan mungkin memerlukan waktu beberapa generasi: Perda 'generasi pertama' membuat kerangka kerjanya, kemudian diikuti oleh Perda 'generasi kedua' yang benar-benar membuat berbagai peraturan yang sesungguhnya.

Karena sifatnya politis, sebuah kerangka kerja Perda memiliki beberapa keuntungan tambahan. Kerangka kerja ini tidak untuk mengatur para pihak yang berkepentingan secara berlebihan, sehingga tidak ada satu pun pihak yang merasa ditinggalkan , dan akhirnya hanya akan menimbulkan perselisihan dan mengurangi kegunaannya. Sebaliknya, kerangka kerja seperti ini bermanfaat untuk meningkatkan jumlah konstituen untuk masalah tertentu, seperti pentingnya meningkatkan pengelolaan sumber daya alam untuk kepentingan semua pihak. Masalahmasalah politis yang sulit, seperti peraturan-

Gambar 2. Menyusun Kerangka Kerja Peraturan Daerah (Perda)

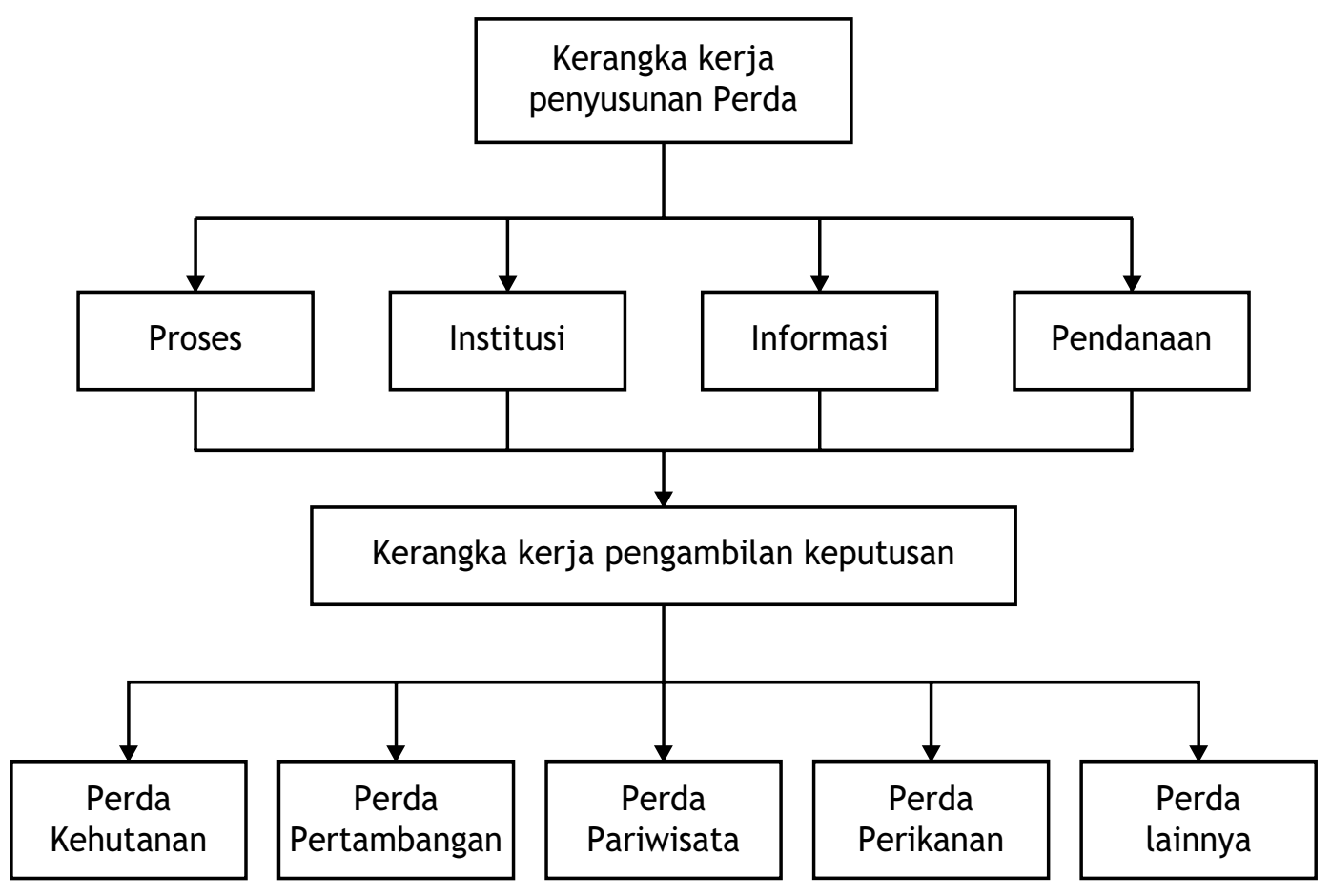


peraturan khusus, dapat ditangani kemudian, setelah landasan politik dan masyarakat madani yang berpendidikan terbentuk.

\section{Kerangka Hukum yang Bersifat Sukarela dan Wajib}

Peraturan perundangan adalah sebuah perangkat untuk membentuk berbagai pola perilaku. Peraturan dapat berperan sebagai salah satu dari dua cara berikut: mendorong pola-pola perilaku tertentu, atau mewajibkan untuk berperilaku seperti yang diinginkan. Sebuah Perda yang isinya preskriptif umumnya bersifat memerintah, dan membutuhkan aparat pemerintahan yang kuat untuk melaksanakan dan menegakkannya. Sebaliknya, Perda yang deskriptif merefleksikan pola-pola perilaku yang ada di masyarakat, dan tidak akan memaksa untuk mengubah perilaku; karena itu, tidak memerlukan aparat pemerintahan yang kuat.

Pada umumnya sebuah Perda berisi sejumlah aturan yang sifatnya wajib untuk ditaati oleh masyarakat. Peraturan yang sifatnya memerintah biasanya merupakan pemaksaan kemauan penguasa atas sekelompok masyarakat (Hart 1961). Peraturan semacam ini bisa jadi atau tidak merefleksikan kemauan kelompok masyarakat tersebut; dan mungkin atau tidak mungkin menunjukkan kemampuan golongan masyarakat tersebut. Peraturan seperti ini sangat sulit ditegakkan, dan umumnya memerlukan investasi sumber daya yang besar-manusia, dana, dan pelatihan-yang mungkin tidak dimiliki oleh Pemda. Jika Perda itu merefleksikan kemauan masyarakat, atau jika Pemda dapat menegakkan peraturan dengan baik, maka Perda ini akan berhasil. Namun, jika Perda tersebut tidak merefleksikan kemauan masyarakat, atau jika Perda tersebut tidak menunjukkan kemampuan masyarakat, serta penegakkannya lemah, maka Perda tersebut akan gagal. Dalam banyak hal, dan ini skenario yang kedua -lemahnya penegakan-yang lebih sering terjadi. Karena itu, Perda-perda yang lebih menekankan kewajiban dan nampak memiliki kekuatan di atas kertas, dalam kenyataannya seringkali lemah dan diabaikan di lapangan.

Tipe Perda lainnya adalah yang didasarkan atas insentif, yang berusaha untuk mendorong pola-pola perilaku tanpa memaksakannya. Perda 'sukarela' semacam ini tidak membutuhkan aparat pemerintahan yang kuat. Namun dalam kenyataannya, Perda seperti ini relatif sering tidak dipatuhi, karena insentif-insentif untuk mempertahankan status quo sering jauh lebih dipentingkan daripada insentif untuk mengikuti program baru.

Pendekatan yang optimal adalah dengan menggabungkan kedua tipe aturan: sesuatu yang didasarkan pada pola-pola perilaku deskriptif tetapi bergerak menuju ke sesuatu yang preskriptif. Tipe Perda ini dapat dibuat berdasarkan model sukarela yang berbasis insentif. Insentif akan diberikan jika syarat-syarat yang diperlukan dipenuhi-Pemda perlu menyusun berbagai Perda dan program sesuai dengan standar dan petunjuk tertentu untuk memastikan bahwa mereka akan mengikutinya dengan baik. Perda seperti ini menghindari harapan-harapan yang tidak realistis, yang sering menyertai sebuah Perda yang bersifat preskriptif, yang memerintahkan berbagai larangan dan persyaratan, dan kemungkinan penegakkannya sangat kecil. Perda yang berdasarkan insentif dapat membangkitkan pola-pola perilaku dengan arah tertentu tanpa perlu memaksakan polapola perilaku tersebut. Memang benar, program sukarela berbasis insentif seperti ini memiliki banyak keterbatasan. Perilaku mungkin tidak berubah karena perubahan tidak diperlukan. Namun, pendekatan ini tetap lebih menjanjikan daripada aturan yang sifatnya memerintah, yang pada kenyataannya sama sekali tidak dijalankan. 


\section{Kesimpulan}

Pengelolaan hutan dan tata kelola di Indonesia telah mengalami perubahan signifikan yang sangat pesat sejak tahun 1998, terutama perubahan kewenangan dari Pemerintah Pusat ke Pemerintah Daerah. Selain itu, sistem pembuatan Undang-Undang dan peraturan, yang biasanya dilakukan oleh lembaga administratif, sekarang oleh lembaga legislatif. Kebijakan otonomi daerah juga telah menyebabkan banyak kabupaten baru yang muncul di negeri ini. Karena itu banyak berdiri instansi-instansi pemerintah yang baru, terutama badan legislatif di daerah, yang memiliki peluang-peluang baru dan tanggung jawab dalam mengelola sumber daya hutan. Namun, banyak Pemda baru saat ini mengalami serba kekurangan dalam hal pengalaman, pegawai, ketrampilan, dana, dan sumber daya lainnya untuk menyusun dan melaksanakan Perda baru yang akan mendorong pengelolaan hutan lestari.

Dua aspek yang sangat penting untuk diperhatikan dalam menyusun Perda baru dalam pengelolaan hutan lestari adalah: prinsip-prinsip yang digunakan, dan mekanisme pembuatannya. Para pakar dan praktisi mengidentifikasi sejumlah prinsip yang terkait dengan penguasaan sumber daya hutan untuk mencapai kelestariannya. Sementara banyak prinsip yang terfokus pada akses dan partisipasi, informasi dan keadilan, prinsip-prinsip penting lainnya juga diperlukan untuk mencapai kelestarian-prinsip-prinsip yang berkaitan dengan koordinasi dan integrasi, tanggung gugat, kepastian hukum, kejelasan, dan fleksibilitas administratif. Prinsip-prinsip tata kelola yang baik ini dapat dikelompokkan menjadi tiga aspek, yaitu: proses (bagaimana Perda disusun); substansi (apa yang tertuang dalam Perda tersebut); dan keadilan (bagaimana Perda ini dilaksanakan). Hanya sedikit sekali contoh-contoh yang memperlihatkan bagaimana prinsip-prinsip ini dapat diterapkan secara praktis, khususnya di tingkat Pemda yang memiliki sumber daya yang terbatas. Peraturan daerah mungkin mengenali beberapa prinsip secara umum, dengan ungkapan yang umum, tetapi tanpa penjelasan yang spesifik atau petunjuk pelaksanaannya. Dalam beberapa kasus, kekurangan ini disengaja karena kurangnya kemauan politik; namun dalam kasus-kasus lain, kekurangan ini terjadi karena keterbatasan sumber daya.
Pedoman ini dimaksudkan untuk membantu Pemda dengan mengajukan berbagai alternatif yang konkrit, khususnya dalam menyusun dan menerapkan prinsip-prinsip penyusunan Perda yang sering bersifat abstrak.

Dalam kaitannya dengan mekanisme penyusunan Perda baru, para pakar dan praktisi telah mengidentifikasi sejumlah langkah yang harus diambil dan pertanyaan-pertanyaan yang harus dijawab sebelum inisiatif pembuatan peraturan baru dimulai. Pertanyaan-pertanyaan yang harus dijawab antara lain terkait dengan pengkajian kebutuhan, analisa biaya-manfaat, dan berbagai studi kelayakan tentang kemungkinan implementasi dan penegakan peraturan. Pertanyaan-pertanyaan ini sering diajukan secara abstrak, dan tidak banyak contoh praktis atau implementasi yang dapat digunakan oleh Pemda yang sedang memulai proses tersebut. Meskipun pemerintah pusat mengharuskan untuk membuat laporan penelitian sebelum merancang sebuah Perda, ternyata kualitas laporan yang dibuat pada umumnya kurang memadai dan tanpa menguraikan analisa yang mendalam. Laporan penelitian semacam ini umumnya juga tidak diwajibkan di tingkat daerah. Pedoman umum ini mengusulkan suatu metodologi untuk menyusun Perda baru, termasuk persiapan pembuatan laporan penelitian dengan rincian dan analisa yang dapat memenuhi syarat, dan juga bagaimana menyelenggarakan konsultasi publik dan merevisi rancangan Perda yang sedang dibuat.

Pedoman ini juga membahas dua tipe kerangka kerja perundangan bagi Pemda untuk dipertimbangkan sebagai alternatif Perda yang umumnya bersifat mengatur, sangat preskriptif dengan persyaratan-persyaratan yang sulit, dan yang dalam kenyataannya tidak banyak ditaati dan ditegakkan. Tipe pertama merupakan konsep peraturan berupa kerangka kerja, atau Perda dasar yang bisa dikembangkan lebih lanjut. Perda ini merupakan landasan untuk membuat kerangka kerja hukum dan kelembagaan untuk pengelolaan, tanpa larangan-larangan khusus yang bersifat mengatur dan kemungkinan belum direncanakan dengan baik, dan tentu saja sulit ditegakkan. Untuk Pemda-pemda yang tidak memiliki Perda pengelolaan hutan, pendekatan seperti ini direkomendasikan dalam pedoman ini. 
Kerangka kerja Perda 'generasi pertama' akan menyediakan kerangka kerja hukum dan kelembagaan untuk pengelolaan sumber daya, dan memungkinkan Perda-perda generasi berikutnya dirancang dengan lebih baik, sejalan dengan peningkatan sumber daya dan kemampuan Pemda untuk melaksanakannya. Tipe kedua adalah konsep Perda sukarela yang berdasarkan insentif. Untuk Pemda-pemda yang tidak memiliki sumber daya atau kemauan politik guna melakukan penegakan hukum, tambahan Perda-perda baru yang menuntut persyaratan lebih banyak akan mengalami kegagalan karena tidak ditegakkannya peraturan yang ada. Pedoman ini menyarankan agar Pemda mempertimbangkan penggunaan alternatif-alternatif ini, seperti Perda yang berbasis insentif.

Pedoman ini bukan dimaksudkan sebagai naskah akademis mengenai peraturan perundangan dan tata kelola di sektor kehutanan. Sebaliknya, pedoman ini dimaksudkan sebagai sebuah petunjuk praktis, untuk mengangkat berbagai isu, dan mengusulkan cara-cara praktis yang dengan mudah dapat dilaksanakan. Sasaran pembacanya adalah para pejabat Pemda yang sedang bergulat dengan kenyataan yang dihadapinya sehari-hari yaitu keterbatasan dana dan staf yang dapat diandalkan, kekurangan pengalaman dan pelatihan, dan kepentingan kelompok penguasa di masa lalu yang lebih banyak menentukan aturan pengelolaan hutan. Karena itu, petunjuk-petunjuk yang disajikan di dalam pedoman ini dimaksudkan untuk mengatasi berbagai masalah yang sedang dihadapi sektor kehutanan di Indonesia, yang mungkin secara teori tidak ideal, dan mungkin tidak memuaskan kalangan akademisi yang mendambakan model yang sempurna dari tata kelola yang baik. Sebaliknya, pedoman ini menawarkan berbagai solusi yang dapat dilaksanakan, meskipun belum sempurna, untuk Pemda-pemda yang memiliki keinginan sungguhsungguh untuk mengelola hutannya secara lestari. 


\section{Daftar Pustaka}

Aman, Alfred C., dan Mayton, William T., 2001. Administrative Law, 2d ed., West Group, St. Paul, $\mathrm{MN}$.

Andreen, William L., 2000. Environmental Law and International Assistance: The Challenge of Strengthening Environmental Law in the Developing World, 25 Columbia Journal of Environmental Law, Vol 25, hal. 17, 27.

Arnstein, Sherry R., 1969. A Ladder of Citizen Participation, Journal of the American Institute of Planners, Vol. 35: 216-224.

Asia Foundation, 2002. First Indonesia Rapid Decentralization Appraisal (IRDA): Synopsis Report, Jakarta.

Asian Development Bank, 2002a. Indigenous Peoples/ Ethnic Minorities and Poverty Reduction in Indonesia, Manila.

Asian Development Bank, 2002b. Draft Country Governance Assessment Report: Indonesia. Jakarta.

Axelrod, R.M., 1984. The Evolution of Cooperation. Basic Books, New York, NY.

Barr, Christopher, dkk., 2001. The Impacts of Decentralization on Forests and Forest-Dependent Communities in Kabupaten Malinau, East Kalimantan: Case Study 3 on Decentralisation and Forests in Indonesia, Center for International Forestry Research, Bogor, Indonesia.

Bell, Gary F., 2001. The New Indonesian Laws Relating to Regional Autonomy: Good Intentions, Confusing Laws, Asian-Pacific Law \& Policy Journal, Vol. 2, hal. 1.

Bennett, C.P.A., 2001. Village Governance and Decentralisation of Natural Resource Management in Indonesia: Of "Responsibility", Accountability and National Unity. dalam Colfer, C.J.P. and Resosudarmo, I.A.P. (eds.) 2002. Which Way Forward? People, Forests, and Policymaking in Indonesia. Resources for the Future (RFF), Washington, D.C.

Blumenthal, Dan dan Jannink, Jean-Luc, 2000. A Classification of Collaborative Management Methods, Conservation Ecology 4(2): 13. (www.consecol.org/vol4/iss2/art13).

Borrini-Feyerabend, ed., Beyond Fences: Seeking
Social Sustainability in Conservation, IUCN, 1997, p. 14.

Botchway, Francis, 2001. Good Governance: The Old, the New, the Principle, and the Elements, Florida Journal of International Law, Vol 13, hal. 159, 161.

Brown, Timothy H., 1999. Economic Crisis, Fiscal Decentralization and Autonomy: Prospects for Natural Resource Management. Jakarta, diterbitkan oleh the Natural Resources Management Project.

Casson, Anne, 2001. Decentralisation of Policies Affecting Forests and Estate Crops in Kotawaringin Timur District, Central Kalimantan: Case Study 5 on Decentralisation and Forests in Indonesia, Center for International Forestry Research, Bogor.

Cicin-Sain, Biliana dan Knecht, Robert W., 1998. Integrated Coastal and Ocean Management: Concepts and Practices, Washington, D.C.: Island Press.

CIFOR Long Loreh team, 2001. Tim terdiri dari: Godwin Limberg, Njau, Ramses, Made, Moira Moeliono, Tony Djogo. Komunikasi Pribadi, 3-25 Mei.

Departemen Dalam Negeri, 2002a. Surat Edaran No. 100/756/OTDA tentang Penyusunan Kewenangan Wajib dan Standar Pelayanan Minimal (8 Juli 2002), ditujukan kepada Sekretaris Jenderal Departemen and Lembaga Pemerintah NonDepartemen, http://www.gtzsfdm.or.id/ documents/laws_n_regs/others/SE-8Juli02SEKTOR\%20SEK-DEP-LPND.pdf.

Departemen dalam Negeri, 2002b. Surat Edaran No. 100/757/OTDA tentang Penyusunan Kewenangan Wajib dan Standar Pelayanan Minimal (8 Juli 2002), ditujukan kepada para Gubernur Provinsi, Bupati, dan Walikota. http://www.gtzsfdm.or.id/ documents / l aws_n_regs / others / SE_KWandSPM_Gubernur_Juli2002.pdf.

Dicey, A.V. 1958. Introduction to the Study of the Law of the Constitution Part II.

Donor SMP Working Group, 2002. Local Government Obligatory Functions and Minimum Service Standards: A Proposal for Conceptual Development and Implementation, draft tidak 
dipublikasikan, Juni. (The Donor SMP Working Group terdiri dari: United States Agency for International Development, the Deutsche Gesellschaft für Technische Zusammenarbeit, the Canadian International Development Agency, the Japanese International Cooperation Agency, the Australian Agency for International Development, The World Bank, the Asian Development Bank, dan the United Nations Development Program).

Estache, Antonio, ed. Decentralizing Infrastructure: Advantages and Limitations, World Bank Discussion Paper 290, Washington D.C., 1995, hal. 18

Fisman, Raymond dan Gatti, Roberta, 1999. Decentralization and Corruption: Cross-County and Cross-State Evidence. The World Bank, Washington, D.C.

GTZ (Deutche Gesellschaft fur Technische Zusammenarbeit), 2001. Project Support for Decentralization Measures (SfDM), Decentralization News Issues No. 1-8. Tersedia di situs: http://www.gtzsfdm.or.id. Agustus. 2001.

Gurodaboro, Moses, 2001. Bagian Hukum, Kantor Bupati, Kabupaten Malinau. Komunikasi Pribadi 26 Mei.

Hart, H.L.A., 1961. The Concept of Law. Oxford, England: Oxford University Press.

Hofman, Bert dan Kaiser, Kai, 2002. The Making of the Big Bang and Its Aftermath: A Political Economy Perspective. Makalah disampaikan pada Konperensi "Can Decentralization Help Rebuild Indonesia?" oleh International Studies Program, Andrew Young School of Policy Studies, Georgia State University. 1-3 Mei. Atlanta.

Impang, Lungu, 2001. Kepala Desa Langkap, Malinau. Komunikasi Pribadi, 15 Mei.

International Tropical Timber Council, 2001. Achieving Sustainable Forest Management in Indonesia: Report Submitted to the ITTC by the Mission Established Pursuant to Decisions 12 (XXIX) 'Strengthening Sustainable Forest Management in Indonesia, 31 $1^{\text {st }}$ Session, 29 Okt.-3 Nov., Yokohama, Japan.

Kre, Ipo, 2001. Kepala Adat, komunikasi pribadi 17 Mei.

Lindsay, Jonathan M., 2000. Creating Legal Space for Community Based Management: Principles and Dilemmas, in Decentralization and Devolution of Forest Management in Asia and the Pacific, ed. Thomas Enters, Patrick B. Durst and Michael Victor, RECOFTC Report No. 18 and RAP Publication, 2000, Bangkok, Thailand.

Lindsay, Jon, Ali Mekour dan Lawrence Christy, 2002. Why Law Matters: Design Principles for Strengthening the Tole of Forestry Legislation in Reducing Illegal Activities and Corrupt Practices, FAO Development Law Service, FAO Legal Papers Situs nomor 27, http://www.fao.org/Legal/ pb-e.htm.
Lynch, Owen J. dan Emily Harwell, 2002. Whose Natural Resources? Whose Common Good? Towards a New Paradigm of Environmental Justice and the National Interest in Indonesia, CIEL. Jakarta, hal. 142.

Mariasa, I.G.P., 2001. Pimpinan, PT Inhutani II SubUnit Malinau. Kabupaten Malinau, Kalimantan Timur, komunikasi pribadi, 11 Mei.

McCarthy, John F., 2001. Decentralisation, Local Communities and Forest Management in Barito Selatan District, Central Kalimantan: Case Study 1 on Decentralisation and Forests in Indonesia, Center for International Forestry Research, Bogor, hal.11-13.

Ostrom, E. 1992. The rudiments of a theory of the origins, survival and performance of commonproperty institutions. Hal. 293-318 dalam DW Bromley dkk. Eds., Making the commons work: Theory, practice, and policy, ICS Press, Oakland CA.

Patlis, J.M., Dahuri, R., Knight, M. dan Tulungen, J., 2001. Integrated Coastal Management in a Decentralized Indonesia: How It Can Work, Jurnal Pesisir \& KelautanVol. 4, No. 1, Bogor, Indonesia.

Patlis, Jason, 2002. Mapping Indonesia's Forest Estate from the Lawyer's Perspective: Laws, Legal Fictions, Illegal Activities, and the Gray Area. Pengkajian Awal yang tidak dipublikasikan, disiapkan untuk The World Bank-World Wildlife Fund Alliance, Jakarta.

Patlis, Jason, Knight, Maurice dan Benoit, Jeff, 2003. Integrated Coastal Management in Decentralizing Developing Countries: The General Paradigm, the U.S. Model and the Indonesian Example, The Ocean Yearbook, Vol. 17, U. Chicago Press, Chicago, IL.

Reuben, William, 2003. The Role of Civic Engagement and Social Accountability in the Governance Equation, Social Development Notes, Note No. 75, The World Bank, Washington, D.C.

Seidman, Ann dan Seidman, R.B., 1997. Beyond Contested Elections: the Process of Bill Creation and the Fulfillment of Democracy's Promises to the Third World, Harvard Journal on Legislation, Vol 34, hal. 1.

Seidman, Ann, Seidman, R.B. dan N. Abeyesekere, 2001. Legislative Drafting for Democratic Social Change: A Manual for Drafters. Boston, Mass.: Kluwer Law International.

Simarmata, Rikardo, 2003. Regional Autonomy and the Character of Local Government Laws and Regulations New Pressures on the Environment and Indigenous Communities: A Preliminary Diagnosis, Paper submitted for the International Association for the Study of Common Property 9th Biennial Conference, Victoria Falls, Zimbabwe.

Smith, Scott dan Martin, Alejandra, 2000. Achieving Sustainability of Biological Conservation: Report 
of a GEF Thematic Review. Monitoring and Evaluation Working Paper I. Global Environment Facility.

Tendler, Judith, 1997. Good Government in the Tropics, The Johns Hopkins University Press, Baltimore, hal. 146.

Thorburn, Craig , 2002. Community Development Advisor, Bejis Project, AusAID. Komunikasi Pribadi, 23 Mei.

Pope, Jeremy, 2000. Confronting Corruption: The Elements of a National Integrity System (TI Source
Book), Transparency International, Berlin.

Turner, Mark dan Hulme, David, 1997. Governance, Administration and Development: Making the State Work. Kumarian Press, West Hartford, CT., hal. 122-124.

U.S. Embassy, 1999. Economic Report: Where the (Natural Resource) Wealth Is, 18 Mei.

World Resources Institute, 2002. Closing the Gap: Access to Information, Participation, and Justice in Decision-Making for the Environment. Washington, DC.

\section{Publikasi terkait}

Case Study 1. McCarthy, J.F. 2001. Decentralisation, local communities and forest management in Barito Selatan District, Central Kalimantan. Center for International Forestry Research, Bogor, Indonesia.

Case Study 2. McCarthy, J.F. 2001. Decentralisation and forest management in Kapuas District, Central Kalimantan. Center for International Forestry Research, Bogor, Indonesia.

Case Study 3. Barr, C., Wollenberg, E., Limberg, G., Anau, N., Iwan, R., Sudana, I.M., Moeliono, M., and Djogo, T. 2001. The Impacts of decentralisation on forests and forest-dependent communities in Malinau District, East Kalimantan. Center for International Forestry Research, Bogor, Indonesia.

Case Study 4. Casson, A. 2001. Decentralisation of policymaking and administration of policies affecting forests and estate crops in Kutai Barat District, East Kalimantan. Center for International Forestry Research, Bogor, Indonesia.

Case Study 5. Casson, A. 2001. Decentralisation of policymaking and administration of policies affecting forests and estate crops in Kotawaringin Timur District. Central Kalimantan. Center for International Forestry Research, Bogor, Indonesia.

Case Studies 6 and 7. Potter, L. and Badcock, S. 2001. The effects of Indonesia's decentralisation on forests and estate crops: Case study of Riau province, the original districts of Kampar and Indragiri Hulu. Center for International Forestry Research, Bogor, Indonesia.

Case Study 8. Soetarto, E., Sitorus, M.T.F. and Napiri, Y. 2001. Decentralisation of administration, policy making and forest management in West Kalimantan. Center for International Forestry Research, Bogor, Indonesia.

Case Study 9. Obidzinski, K. and Barr, C. 2002. The effects of decentralisation on forests and forest Industries in Berau District, East Kalimantan. Center for International Forestry Research, Bogor, Indonesia.

\section{Publikasi lainnya}

Anau, N., Iwan, R., van Heist, M., Limberg, G., Sudana, M. and Wollenberg, E. 2002. Negotiating More than Boundaries: Conflict, Power and Agreement Building in the Demarcation of Village Borders in Malinau, 131156. In: Technical Report Phase I 1997-2001. ITTO Project PD 12/97 Rev.1 (F) Forest, Science and Sustainability: The Bulungan Model Forest. Center for International Forestry Research, Bogor, Indonesia.

Casson, A. and Obidzinski, K. 2002. From New Order to Regional Autonomy: Shifting Dynamics of Illegal Logging in Kalimantan, Indonesia. World Development 30(12):2133-51.

Resosudarmo, I.A.P. 2003. Shifting Power to the Periphery: The Impact of Decentralisation on Forests and Forest People. In: Aspinall, E. and Fealy, G. (eds.) Local Power and Politics in Indonesia: Decentralisation and Democratisation, 230-244. Singapore, Institute of Southeast Asian Studies.

Oka, N.P. and William, D. 2004. The Policy Dilemma for Balancing Reforestation Funds. Decentralisation Brief. No. 1. Center for International Forestry Research, Bogor, Indonesia.

Colfer, C.J.P. and Resosudarmo, I.A.P. (eds). 2002. Which Way Forward: People, Forests and Policymaking in Indonesia. Washington, Resources for the Future. 

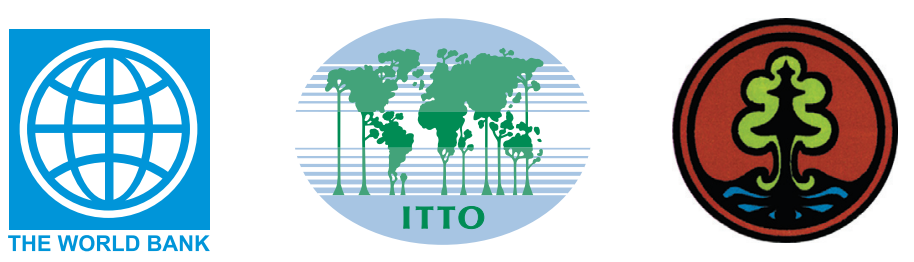

Program Forests and Governance di CIFOR mengkaji cara pengambilan dan pelaksanaan keputusan berkenaan dengan hutan dan masyarakat yang hidupnya bergantung dari hutan. Tujuannya adalah meningkatkan peran serta dan pemberdayaan kelompok masyarakat yang kurang berdaya, meningkatkan tanggung jawab dan transparansi pembuat keputusan dan kelompok yang lebih berdaya dan mendukung proses-proses yang demokratis dan inklusif yang meningkatkan keterwakilan dan pengambilan keputusan yang adil di antara semua pihak. 